\title{
Revisión bibliográfica de los artículos publicados de cirugía bucal en el año 2005
}

\section{Literature review of oral surgery articles published in 2005}

\author{
C. Larrazábal Morón', S. Galán Gil', M. Peñarrocha Diago³
}

Resumen: Introducción. El objetivo de este trabajo es revisar los artículos de cirugía oral publicados en el año 2005.

Material y método. Tres revisores han realizado una búsqueda en las revistas indexadas en Medline, clasificando los artículos de acuerdo a diferentes temas. Los criterios de búsqueda fueron: artículos de especial interés publicados en revistas de impacto nacional e internacional, que actualizaran cualquiera de los temas señalados.

Resultados. Los artículos más interesantes sobre cirugía bucal publicados en el año 2005 son: 11 artículos sobre quistes, 35 de tumores de los maxilares y tejidos blandos, 4 de infecciones de los maxilares, 11 de cirugía periapical, 15 de patología del tercer molar, 5 de inclusiones dentarias, 11 de transplantes y reimplantes dentarios, 5 de fármacos y 3 artículos de otros temas.

Conclusión. Aportar a otros investigadores una rápida identificación de los artículos más importantes de cirugía bucal publicados en el año 2005.

Palabras clave: Cirugía bucal; Revisión bibliográfica.

Recibido: 01.08 .06

Aceptado: 21.07 .08
Abstract: Introduction. Oral surgery articles published in 2005 were reviewed.

Material and method. Three reviewers searched journals indexed in Medline and classified the articles by topic. The search criteria were: articles of special interest, published in national and international impact journals, that updated any of the topics selected. Results. The most interesting articles on oral surgery published in 2005 were: 11 articles on cysts, 35 on jaw and soft tissues tumors, 4 jaw infections, 11 periapical surgery, 15 third molar pathology, 5 dental impaction, 11 dental transplantation and reimplantation, 5 drugs, and 3 articles on other topics.

Conclusion. The authors offer other researchers a quick overview of the most important articles in oral surgery published in 2005.

Key words: Oral surgery; Literature review.

1 Máster de Cirugía e Implantología Oral.

2 Profesor Titular de Cirugía Bucal. Director del Máster de Cirugía e Implantología Oral. Facultad de Medicina y Odontología. Universidad de Valencia. España

\section{Correspondencia:}

Miguel Peñarrocha Diago

Facultad de Medicina y Odontología

Gascó Oliag, 1

46021 Valencia. España

Email: penarroc@uv.es 


\section{Introducción}

Presentamos una revisión bibliográfica de los artículos más interesantes sobre cirugía bucal publicados en el año 2005. Se ha realizado la búsqueda en las revistas indexadas en Medline, dividiendo los temas por apartados (quistes, tumores de los maxilares y tejidos blandos, infecciones de los maxilares, cirugía periapical, patología del tercer molar, inclusiones dentarias, transplantes y reimplantes dentarios, fármacos y otros temas) para facilitar la lectura y búsqueda de información. De esta manera otros investigadores pueden consultar las fuentes bibliográficas que hemos citado.

\section{Material y método}

Se realizó una búsqueda en las revistas indexadas en Medline en el año 2005, clasificando los artículos de acuerdo a diferentes temas. Los criterios de búsqueda fueron: artículos de especial interés publicados en revistas de impacto nacional e internacional, que actualizaran cualquiera de los temas señalados.

\section{Resultados}

\section{Quistes}

Dentro de los quistes epiteliales odontogénicos, la proteína BMP4 está muy presente en la diferenciación y proliferación celular. Seong y cols. ${ }^{1}$ compararon la diferencia de expresión de la proteína evaluando histológicamente 34 queratoquistes y 43 quistes dentígeros. La presencia de de la proteína BMP-4 fue más intensa en los queratoquistes odontogénicos que en los quistes dentígeros.

El síndrome névico basocelular también conocido como síndrome de Gorlin-Goltz, es un trastorno de herencia autosómica dominante que se caracteriza por la presencia de queratoquistes múltiples maxilares y carcinomas basocelulares faciales. Díaz y cols. ${ }^{2}$ realizaron una revisión de la literatura y presentaron seis casos de pacientes afectos de síndrome névico baso-celular, a los que se les realizó bajo anestesia general la exéresis de los quistes maxilares.

Los quistes dentígeros, habitualmente se asocian a coronas de dientes permanentes. Smith y cols. ${ }^{3}$ realizaron un estudio retrospectivo desde 1975 al 2004 en 327 radiografías de pacientes con infecciones de cabeza y cuello para evaluar la presencia de quistes dentígeros asociados a infecciones; encontraron 7 casos $(2,1 \%)$, la localización más frecuente fue la rama mandibular, envolviendo el tercer molar incluido y la edad media fue de 46 años. Todos fueron tratados mediante enucleación del quiste y solo un paciente mostró recurrencias.

Edamatsu y cols. ${ }^{4}$ estudiaron la apoptosis celular de los folículos dentales y de los quistes dentígeros asociados a terceros molares incluidos, examinaron Fas, bcl-2 y ssDNA, los resultados se compararon con la inmunoreactividad al Ki-67, un marcador de proliferación celular. La muestra estaba formada por 80 folículos dentales (FD) y 27 quistes dentígeros (QD) asociados a terceros molares mandibulares incluidos, los resultados indicaron que la presencia de la proteína bcl-2 fue más baja en los folículos dentales que

\section{Introduction}

We present a review of the most interesting articles on oral surgery published in 2005. We searched journals indexed in Medline, dividing topics by sections (cysts, jaw and soft tissue tumors, jaw infections, periapical surgery, third molar pathology, dental impaction, dental transplantation and reimplantation, drugs, and other topics) to facilitate reading and the search for information. The articles are briefly discussed for other investigators.

\section{Material and method}

A search was made of articles published in 2005 in journals indexed in Medline. Articles were classified by topic. The search criteria were: articles of special interest, published in national and international impact journals, that updated one of the topics selected.

\section{Results}

Cysts

BMP-4 protein intervenes in the cellular differentiation and proliferation of odontogenic epithelial cysts. Seong et al. ${ }^{1}$ compared BMP-4 protein expression in histologic analysis of 34 keratocysts and 43 dentigerous cysts. The presence of BMP-4 protein was more intense in odontogenic keratocysts than in dentigerous cysts.

Basal cell nevus syndrome, also known as Gorlin-Goltz syndrome, is an autosomal dominant hereditary disorder characterized by the presence of multiple maxillary keratocysts and facial basal cell carcinomas. Díaz et al..$^{2}$ reviewed the literature and presented six cases of patients with basal cell nevus syndrome in which maxillary cysts were resected under general anesthesia.

Dentigerous cysts usually are associated with third-molar crowns. Smith et al. ${ }^{3}$ made a retrospective study from 1975 to 2004 of 327 radiographs of patients with head and neck infections to evaluate the presence of dentigerous cysts associated with infections. They found 7 cases (2.1\%). The most frequent location was the mandibular ramus, surrounding an impacted third molar. The mean age of patients was 46 years. All of the patients were treated by cyst enucleation and only one patient had a recurrence.

Edamatsu et al. ${ }^{4}$ studied cellular apoptosis in dental follicles and dentigerous cyst associated with impacted third molars. They examined Fas, bcl-2, and ssDNA and compared the results with Ki67 immunoreactivity, a marker of cellular proliferation. The sample was formed by 80 dental follicles (DF) and 27 dentigerous cysts (DC) associated with mandibular impacted third molars. The results indicated less bcl-2 protein in dental follicles that in dentigerous cysts. However, ssDNA was slightly more abundant in dental follicles and Ki67 pro- 
en los quistes dentígeros, sin embargo la ssDNA fue ligeramente más numerosa en folículos dentales y la proteína Ki67 fue predominante en los quistes dentígeros. Los folículos dentales inflamatorios mostraron positividad ligeramente más alta, para el ssDNA y Ki67, que los folículos dentales sin origen inflamatorio.

El quiste odontogénico glandular es una lesión poco frecuente y se debe hacer un diagnóstico diferencial con otras lesiones radiotrasparentes. Kaplan y cols. ${ }^{5}$ revisaron 56 casos de quiste odontogénico glandular, 49 publicados en la literatura y 7 casos propios, en 34 hombres y 22 mujeres, con una edad media de 48 años. El $73,2 \%$ aparecieron en maxilar y el $26,8 \%$ en la mandíbula, la localización en la mayoría de los casos fue la zona anterior. Radiográficamente, el 53,6\% eran uniloculares y el $46,4 \%$ multiloculares, la cortical se mantuvo íntegra en el 53,6\%, el 39,3\% presentaron perforación, y el 14,3 erosión de la misma. Recidivaron un 29,2\%, a los 2,9 años de media, que se asoció a cirugías menores, como la enucleación o el curetaje. Ninguno de los pacientes tratados con ostectomía periférica, resección marginal, ni resección parcial de la mandíbula presentaron recurrencias.

Qin y cols. ${ }^{6}$ publicaron 14 casos de quiste odontogénico glandular, recogidos en los últimos 50 años. Basaron el diagnóstico en los hallazgos histopatológicos y las imágenes de la ortopantomografía y tomografía computerizada. Se localizaron 9 en el maxilar y 3 en la mandíbula, en la zona anterior y de los molares. Ninguno produjo afectación de la rama mandibular ni del seno maxilar. El estudio radiológico mostró 11 lesiones uniloculares y 3 multiloculares. Todas las lesiones fueron tratadas quirúrgicamente.

Kaplan y cols. ${ }^{7}$ estudiaron la presencia de marcadores moleculares como p53, PCNA y Ki67 en 35 pacientes que presentaban 10 quistes odontogénicos glandulares, 15 quistes radiculares y 9 carcinomas mucoepidermoides. La presencia de la proteína p53 fue mayor en los dos primeros que en los quistes radiculares, al contrario que la proteína Ki67 que su presencia fue mayor en los quistes odontogénicos glandulares y en los quistes radiculares que en los carcinomas mucoepidermoides. No se encontraron diferencias estadísticamente significativas con la proteína PCNA. Los marcadores p53 y Ki67 ayudaron en el diagnóstico diferencial del quiste odontogénico glandular.

Respecto a los quistes epiteliales del desarrollo no odontogénicos, Tanimoto y cols. ${ }^{8}$ presentaron una mujer de 39 años con una tumefacción que elevaba el ala nasal en su unión con el labio superior. No se observó ninguna anormalidad en la ortopantomografía. Tras realizar una resonancia magnética con contraste y visualizar la lesión, se realizó la escisión quirúrgica de la misma y el análisis histológico estableció el diagnóstico de quiste nasoalveolar.

Takeda y cols. ${ }^{9}$ estudiaron la incidencia de células ciliadas y mucosas del epitelio de quistes inflamatorios (205 quistes radiculares) y del desarrollo (130 quistes dentígeros y 26 primordiales). Encontraron células mucosas en el $20,8 \%$ de los quistes examinados, y células ciliadas en el $11,4 \%$ del total. No apreciaron diferencias significativas en las proporciones de estas células entre los distintos quistes. Concluyeron que las células ciliadas y mucosas en el epitelio de los quistes odontogénicos intraóseos son de origen metaplásico, pero la causa de su origen y su significado biológico permanecen sin aclarar. tein was predominant in odontogenic cysts. Inflammatory dental follicles were slightly more positive for ssDNA and Ki67 than dental follicles of non-inflammatory origin.

Glandular odontogenic cysts are infrequent. The differential diagnosis must be made with other radiolucent lesions. Kaplan et al. 5 reviewed 56 cases of glandular odontogenic cyst, 49 published in the literature and 7 of their own cases, in 34 men and 22 women with a mean age of 48 years. Seventy-three percent (73.2\%) appeared in the maxilla and $26.8 \%$ in the jaw; in most cases in the anterior part. Radiographically, $53.6 \%$ were unilocular and $46.4 \%$ were multilocular. The cortex remained intact in 53.6\%, 39.3\% presented perforation, and $14.3 \%$, cortical erosion. In $29.2 \%$, there was recurrence, at a mean of 2.9 years, which was associated with minor surgery like enucleation or curettage. None of the patients treated with peripheral ostectomy, surgical margin resection, or partial jaw resection presented recurrence.

Qin et al. ${ }^{6}$ published 14 cases of glandular odontogenic cyst collected in the last 50 years. They based the diagnosis on histopathologic findings and orthopantomography and computed tomography imaging. Nine were located in the maxilla and 3 in the mandible, anterior zone, and molars. None involved the mandibular ramus or maxillary sinus. The radiologic study showed 11 unilocular and 3 multilocular lesions. All lesions were treated surgically.

Kaplan et al. ${ }^{7}$ studied the presence of molecular markers like p53, PCNA and Ki67 in 35 patients who presented 10 glandular odontogenic cysts, 15 radicular cysts, and 9 mucoepidermoid carcinomas. The presence of $p 53$ protein was greater in glandular odontogenic and mucoepidermoid carcinoma than in the radicular cysts, in contrast with Ki-67 protein, which had a greater presence in glandular odontogenic cysts and radicular cysts than in mucoepidermoid carcinomas. No statistically significant differences were found with PCNA protein. The p53 and Ki67 markers helped in the differential diagnosis of glandular odontogenic cyst.

With respect to developmental non-odontogenic epithelial cysts, Tanimoto et al. ${ }^{8}$ reported the case of a 39-yearold woman with swelling that raised the junction of the external nare with the upper lip. No abnormality was observed in orthopantomography. After performing magnetic resonance imaging with contrast and visualizing the lesion, it was excised surgically. Histologic study established the diagnosis of nasoalveolar cyst.

Takeda et al. ${ }^{9}$ studied the incidence of ciliated and mucosal cells of the epithelial lining of inflammatory (205 radicular cysts) and developmental cysts (130 dentigerous cysts and 26 primordial cysts). They found mucosal cells in $20.8 \%$ of the cysts examined and ciliated cells in $11.4 \%$ of the total. No significant differences were appreciated in the relative proportion of these cells in the different cysts. They concluded that the ciliated and mucosal cells of the epithelium of intraosseous odontogenic cysts are of metaplastic origin, but the ultimate cause and biological meaning remain unclear. 
Baykul y cols. 10 investigaron los cambios quísticos asociados al tercer molar mandibular incluido y su posición angulada respecto al diente adyacente; en 94 pacientes con edades comprendidas entre los 14-45 años, la mitad de ellos mostraron cambios radiológicos durante los 20-25 años de edad. La relación entre los cambios quísticos y la posición angular fue estadísticamente significativa $(p<05)$. Los terceros molares incluidos posicionados verticalmente presentaron mayor lesión radiológica.

En el diagnóstico diferencial de los quistes, debemos tener en cuenta la cavidad de Stafne. Belmonte y cols. ${ }^{11}$ presentaron un hombre de 68 años con una lesión radiotransparente paramandibular izquierda diagnosticada de quiste radicular, a los 5-6 años de evolución, ante un cambio de tamaño se le realizó una quistectomía. La lesión era de consistencia blanda, color marrón rojizo con componente vascular o glandular salival. Tras el análisis histológico se estableció el diagnóstico definitivo de cavidad de Stafne.

\section{Tumores}

\section{Tumores odontogénicos}

Respecto a los tumores epiteliales sin ectomesénquima, Fernandes y cols. ${ }^{12}$ estudiaron la frecuencia de los tumores odontogénicos en una población brasileña. De 19.123 biopsias de patologías orales revisadas desde 1954 al 2004, 340 fueron tumores odontogénicos $(1,78 \%)$. El tumor más frecuente fue el ameloblastoma $(45,2 \%)$, seguido del odontoma (24,9\%) y el mixoma $(9,1 \%)$.

En una población nigeriana, de edad media 29,9 años, Ladipo y cols. ${ }^{13}$ encontraron en 319 pacientes, una frecuencia de tumores odontogénicos del 9,6\%. Del total, 96,6\% fueron intraóseos y 3,4\% fueron periféricos (fibroma odontogénico periférico $=7$, mixoma periférico $=3$, ameloblastoma periférico $=1$ ). El $96,6 \%$ fueron benignos y $3.4 \%$ malignos. El más frecuente fue el ameloblastoma (63\%), seguido del tumor odontogénico adenomatoide $(7,5 \%)$, del mixoma $(6,5 \%)$, del quiste odontogénico epitelial calcificante $(5,3 \%)$, del fibroma odontogénico $(5,3 \%)$, odontoma $(2,5 \%)$ y del carcinoma ameloblástico $(2,2 \%)$. No hubo diferencias significativas entre la edad de los pacientes que presentaban tumores benignos y malignos.

Simon y cols. ${ }^{14}$ estudiaron la epidemiología y las características clinicopatológicas de los tumores odontogénicos en una población de Tanzania. De 116 pacientes con tumores odontogénicos revisados durante 4 años, el ameloblastoma fue el más frecuente $(80,1 \%)$, seguido del mixoma odontogénico $(7 \%)$; dos presentaron recidiva del ameloblastoma.

Taiwo y cols. ${ }^{15}$ realizaron un estudio retrospectivo clínico-patológico de 990 tumores de los maxilares y lesiones periorales en una población nigeriana, encontrando que 318 de los casos eran tumores odontogénicos (32\%). El 99\% de los tumores fueron benignos, frente a un $1 \%$ malignos. De los tumores benignos, $73 \%$ fueron ameloblastomas, $12 \%$ mixomas odontogénicos, $3 \%$ fibroma ameloblástico, y un $2 \%$ tumor odontogénico adenomatoide. Realizaron el seguimiento de sólo 60 casos de ameloblastoma, de los cuales recidivaron 8 casos.

Artés y cols. ${ }^{16}$ presentaron las características citológicas de dos casos de recidiva yugal de ameloblastoma de rama mandibular,
Baykul et al. 10 investigated cystic changes associated with mandibular impacted third molar and angling with respect to the adjacent tooth. In 94 patients aged 14-45 years, half exhibited radiologic changes at age 20-25 years. The relation between cystic changes and the angular position was statistically significant $(p<.05)$. Vertically positioned impacted third molars showed a more intense radiologic lesion.

In the differential diagnosis of cysts, we must consider the Stafne defect. Belmonte et al. ${ }^{11}$ reported a 68-year-old man with a left paramandibular radiolucent lesion diagnosed as radicular cyst, of 5-6 years of evolution, in which cystectomy was performed due to a change in size. The lesion was of soft consistency and reddish-brown color, with a vascular or salivary gland component. The definitive diagnosis of Stafne defect was established after histologic analysis.

\section{Tumors}

\section{Odontogenic tumors}

With regard to epithelial tumors without ectomesenchyme, Fernandes et al..$^{12}$ studied the frequency of odontogenic tumors in a Brazilian population. Of 19,123 biopsies of oral pathologies reviewed from 1954 to 2004, 340 were odontogenic tumors (1.78\%). The most frequent tumor was ameloblastoma (45.2\%), followed by odontoma (24.9\%), and myxoma (9.1\%).

In a Nigerian population, mean age 29.9 years, Ladipo et al..$^{13}$ found a frequency of odontogenic tumors of $9.6 \%$ in 319 patients. Of the total, $96.6 \%$ were intraosseous and $3.4 \%$ were peripheral (7 peripheral odontogenic fibromas, 3 peripheral myxomas, and 1 peripheral ameloblastoma). Ninety-seven percent (96.6\%) were benign and $3.4 \%$ were malignant. The most frequent odontogenic tumor was ameloblastoma (63\%), followed by adenomatoid odontogenic tumor (7.5\%), myxoma (6.5\%), calcifying odontogenic epithelial cyst (5.3\%), odontogenic fibroma (5.3\%), odontoma $(2.5 \%)$, and ameloblastic carcinoma (2.2\%). There were no significant differences in age between the patients who had benign and malignant tumors.

Simon et al..$^{14}$ studied the epidemiology and clinical and pathologic characteristics of odontogenic tumors in a Tanzanian population. Of 116 patients with odontogenic tumors reviewed in 4 years, ameloblastoma was the most frequent (80.1\%), followed by odontogenic myxoma (7\%). Two patients had a recurrence of ameloblastoma.

Taiwo et al. ${ }^{15}$ made a retrospective clinical-pathological study of 990 tumors of the jaw and perioral lesions in a Nigerian population and found that 318 (32\%) cases were odontogenic tumors. Ninety-nine percent of the tumors were benign and $1 \%$ were malignant. Of the benign tumors, $73 \%$ were ameloblastomas, $12 \%$ odontogenic myxomas, $3 \%$ ameloblastic fibromas, and $2 \%$ adenomatoid odontogenic tumor. They followed up only 60 cases of ameloblastoma, of which 8 recurred. 
mostrando un fondo granular con aislados macrófagos, células multinucleadas gigantes y células escamosas de metaplasma. La citología de estos tumores reveló los componentes de la lesión, suficientes para llegar al diagnóstico de ameloblastoma, especialmente en casos de recidiva.

Torres y cols. ${ }^{17}$ presentaron seis pacientes con ameloblastoma localizados en la mandíbula, siendo la zona más afectada, el cuerpo mandibular (4 casos), seguido de la sínfisis (1 caso) y el ángulo mandibular (1 caso). El sexo femenino presentó una predilección de 2:1 frente al masculino. La edad media de los pacientes fue de 42.3 años. El manejo terapéutico consistió en la extirpación de la lesión, fresado perilesional del hueso o resección en bloque, según el tipo de ameloblastoma. Ninguno de los pacientes presentó recidiva.

Muvova y cols. ${ }^{18}$ realizaron el seguimiento de 92 casos de ameloblastomas recidivantes en mandíbula. Sometieron a los pacientes, 66 de raza negra africana y 26 caucásicos a cirugías conservadoras y los evaluaron en base a criterios bioestadísticos y bioclínicos. El porcentaje de éxito fue mayor del $80 \%$ para las dos razas, lo que situó el tratamiento conservador entre las alternativas para las recidivas en ameloblastomas.

Arotiba y cols. ${ }^{19}$ revisaron la clínica y el tratamiento de 79 casos de ameloblastoma en niños y adolescentes nigerianos. Observaron que era más frecuente en hombres que en mujeres (1.3:1), con una incidencia de 15 años en hombres y 17 en mujeres. Todos los tumores fueron intraóseos y la mayoría se localizaban en la región sinfisal de la mandíbula (57,3\%). La morfología más común fue de ameloblastoma multiquístico (82,3\%), con presentación radiológica multilocular $(66,2 \%)$. La técnica quirúrgica empleada en la mayoría de los casos $(72,2 \%)$ fue la resección.

Patel y cols. ${ }^{20}$ presentaron un caso de ameloblastoma uniquístico similar a un quiste dentígero en un paciente de 14 años de edad con un Síndrome de Gardner. Radiológicamente mostraba una lesión radiotransparente alrededor del segundo premolar inferior incluido, desde el primer molar permanente al canino. El tratamiento de elección fue la resección quirúrgica y curetaje de la lesión.

Por otra parte, Cunha y cols. ${ }^{20}$ presentaron un hombre de 49 años de edad, remitido por la presencia de inflamación en la zona posterior izquierda de la mandíbula, la exploración radiológica mostró una lesión radiotransparente bien definida de $3 \mathrm{~cm}$ de diámetro que afectaba desde el segundo premolar hasta el segundo molar; le realizaron la enucleación y un examen histológico que proporcionó, el diagnóstico de ameloblastoma uniquístico. Diez años antes se detectó una lesión con las mismas características de $1,5 \mathrm{~cm}$ de diámetro que afectaba a la raíz del 36 , se diagnosticó de lesión quística y se recomendó la enucleación pero solo se realizó la extracción del primer molar.

El ameloblastoma desmoplásico es una variante histológica del ameloblastoma. Hirota y cols. ${ }^{22}$ publicaron el caso de una mujer de 17 años con un ameloblastoma localizado en la región mentoniana derecha. Radiológicamente se mostró una zona mixta de radiotransparencia y radioopacidad. Se realizó una maxilectomía parcial para la resección del tumor bajo anestesia general. Después de 7 años de seguimiento, los exámenes clínicos y radiográficos no mostraron recurrencias.
Artés et al. ${ }^{16}$ reported the cytological characteristics of two cases of malar recurrence of ameloblastoma of the mandibular ramus, which exhibited a granular background, isolated macrophages, giant multinucleate cells, and squamous cells of metaplasia. The cytology of these tumors revealed the components of the lesion, which was sufficient to reach the diagnosis of ameloblastoma, especially in cases of recurrence.

Torres et al. ${ }^{17}$ reported six patients with ameloblastoma of the jaw. The zone most affected was the mandibular body (4 cases), followed by the symphysis (1 case), and angle (1 case). The tumor showed a predilection of 2:1 for women with respect to men. The mean age of patients was 42.3 years. The therapeutic management consisted of resection of the lesion, perilesional milling of the bone, or block resection, depending on the type of ameloblastoma. None of the patients had a recurrence.

Muvova et al. ${ }^{18}$ followed up 92 cases of recurrent ameloblastoma of the jaw. The patients, 66 black Africans and 26 Caucasians, underwent conservative surgery and the authors evaluated them using biostatistical and bioclinical criteria. The success rate was more than $80 \%$ for the two races, which made conservative treatment a viable alternative for recurrences in ameloblastomas.

Arotiba et al. ${ }^{19}$ reviewed the clinical manifestations and treatment of 79 cases of ameloblastoma in Nigerian children and adolescents. They observed that it was more frequent in men than in women (1.3:1), with an incidence at 15 years in men and at 17 years in women. All the tumors were intraosseous and the majority were located in the symphyseal region of the jaw (57.3\%). The most common morphology was multicystic ameloblastoma (82.3\%) with a multilocular radiologic presentation (66.2\%). The surgical technique used in most cases (72.2\%) was resection.

Patel et al. ${ }^{20}$ reported a case of dentigerous cyst-like unicystic ameloblastoma in a 14-year-old male patient with Gardner syndrome. Radiologically, the patient exhibited a radiolucent lesion surrounding an impacted second premolar that extended from the first permanent molar to the canine. The treatment of choice was surgical resection and curettage of the lesion.

On the other hand, Cunha et al..$^{20}$ reported the case of a 49-year-old man referred for inflammation in the left posterior zone of the mandible. The radiologic study disclosed a well-defined radiolucent lesion, $3 \mathrm{~cm}$ in diameter, that affected the mandible from the second premolar to the second molar. After enucleation, histologic examination disclosed the diagnosis of unicystic ameloblastoma. Ten years earlier, a lesion with the same characteristics, measuring 1.5 $\mathrm{cm}$ in diameter, had been detected in the root of 3.6. A cystic lesion was diagnosed and enucleation was recommended, but only the first molar was extracted.

Desmoplastic ameloblastoma is a histologic variant of ameloblastoma. Hirota et al. ${ }^{22}$ reported the case of a 17 year-old woman with ameloblastoma located in the right 
El tumor odontogénico calcificante es una lesión odontogénica del desarrollo rara. Hay pocos estudios en la literatura que describan sus características inmunohistoquímicas y su actividad proliferativa. Seim y cols. ${ }^{23}$ estudiaron el caso de un hombre de 53 años, con una lesión radiotransparente unilocular en la región posterior derecha del maxilar. En la tomografía computerizada se muestra la presencia del tercer molar incluido. Se realizó la extracción del mismo, la enucleación y curetaje del tumor. La histología reveló un tumor híbrido formado por un ameloblastoma y un tumor odontogénico epitelial calcificante.

Con respecto a los tumores epiteliales con ectomesénquima con o sin tejidos duros dentales, Chen y cols. ${ }^{24}$ compararon las características clínico-patológicas de 13 fibromas ameloblásticos y 7 fibroodontomas ameloblásticos. La mayoría de los pacientes con fibromas ameloblásticos $(69,2 \%)$ se dieron a los 22 años de edad y se localizaron en la región posterior de la mandíbula (76,9\%). Los fibromas ameloblásticos recurrieron en 4 pacientes de 11 y 2 de ellos mostraron trasformación maligna. Sin embargo, el fibroodontoma ameloblástico se dio a una edad más temprana (9 años), 2 de los 5 pacientes que se les realizó seguimiento presentaron recurrencias con un crecimiento limitado y odontomas complejos.

Handschel y cols. ${ }^{25}$, y Motamedia y cols. ${ }^{26}$ publicaron un tumor odontogénico adenomatoide asociado a un canino incluido, se realizó la extracción del tumor y del diente en el primer caso, y en el segundo el canino fue reposicionado en la arcada mediante ortodoncia. No hubo recidivas.

Barboza y cols. ${ }^{27}$ analizaron la presencia del antígeno nuclear de proliferación celular y de la proteína p53 en 16 casos de ameloblastoma y 8 casos de tumor odontogénico adenomatoide. Los casos de ameloblastoma se clasificaron según su histología en: 7 foliculares, 4 plexiformes, 3 foliculares más acantomatosos y 2 casos de células basales. Los casos de ameloblastoma folicular presentaron mayor expresión positiva para el antígeno nuclear de proliferación celular, sin embargo la proteína p53 se presentaba más fuerte en los ameloblastomas de tipo plexiforme. Los resultados también indicaron que los ameloblastomas tenían mayor potencial proliferativo que el tumor odontogénico adenomatoide.

En ocasiones, el odontoma puede alterar la erupción de algún diente; Nelson P y cols. ${ }^{27}$ presentaron un caso de un niño de un año y ocho meses de edad que sufrió la avulsión del 5.1 tras un traumatismo que además provocó cambios morfológicos en el sucesor permanente. Al año del traumatismo, se observó la formación de una masa parecida a un odontoma. A los 6 años del accidente, realizaron la extirpación quirúrgica del odontoma y la tracción ortodóncica del incisivo, consiguiendo una aceptable alineación del diente en la arcada.

Tomizawa y cols. ${ }^{29}$ presentaron una serie 39 odontomas en 38 niños, (23 hombres y 15 mujeres) con edades comprendidas entre 1,2 y 14 años. El $87 \%$ de los casos fue asociado al retraso de la erupción. La región más afectada fue el sector anterior del maxilar. Se realizó la exéresis quirúrgica en todos los casos y el estudio patológico mostró 30 casos de odontoma compuesto, 7 de odontoma complejo y 2 casos de odontoma mixto. Se encontró una recidiva a los seis años. mental region. A zone of mixed radiolucency and radiopacity was evident on radiography. Partial maxillectomy was performed during tumor resection under general anesthesia. After 7 years of follow-up, clinical and radiographic examination did not disclose any recurrence.

Calcifying odontogenic tumor is a rare developmental odontogenic lesion. Few studies in the literature have described its immunohistochemical characteristics and proliferative activity Seim et al..$^{23}$ studied the case of a 53-year-old man with a unilocular radiolucent lesion in the right posterior jaw. Computed tomography showed an impacted third molar. The third molar was removed and tumor enucleation and curettage was performed. Histopathologic study revealed a hybrid tumor formed by an ameloblastoma and calcifying epithelial odontogenic tumor.

In a study of epithelial tumors with ectomesenchyme, with or without dental hard tissue, Chen et al. ${ }^{24}$ compared the clinical and pathologic characteristics of 13 ameloblastic fibromas and 7 ameloblastic fibro-odontomas. In most of the patients with ameloblastic fibroma (69.2\%), the tumor occurred at 22 years of age and was located in the posterior part of the mandible (76.9\%). Ameloblastic fibromas recurred in 4 of 11 patients; 2 of them exhibited malignant transformation. In contrast, ameloblastic fibro-odontoma occurred at an earlier age (9 years) and 2 of the 5 patients followed up exhibited recurrence with limited growth and complex odontomas.

Handschel et al. ${ }^{25}$ and Motamedia et al. ${ }^{26}$ reported adenomatoid odontogenic tumors associated with an impacted canine. The tumor and tooth were excised in the Handschel case and the canine was repositioned in the dental arcade by orthodontics in the Motamedia case. There were no recurrences.

Barboza et al. ${ }^{27}$ analyzed the presence of proliferating cell nuclear antigen and p53 protein in 16 cases of ameloblastoma and 8 cases of adenomatoid odontogenic tumor. The ameloblastoma cases were classified by histology as: $7 \mathrm{fol}-$ licular, 4 plexiform, 3 follicular and acanthomatic, and 2 basal cell. The cases of follicular ameloblastoma showed more positive proliferating cell nuclear antigen expression, whereas p53 protein expression was stronger in plexiform type ameloblastomas. The results also indicated that ameloblastomas had more proliferative potential than adenomatoid odontogenic tumors.

Odontoma sometimes can disturb tooth eruption. Nelson et al. ${ }^{27}$ reported the case of a 20-month-old boy who had suffered 5.1 avulsion after trauma, that also caused morphologic changes in the permanent successor tooth. One year after the injury, fan odontoma-like mass had formed. Six years after the accident, the odontoma was surgically resected and orthodontic alignment was performed on the incisor, resulting in acceptable tooth alignment in the dental arcade.

Tomizawa et al..$^{29}$ presented a series of 39 odontomas in 38 children, (23 boys and 15 girls), age 1.2 to 14 years. 
Gallana y cols., 30 observaron en un paciente de 19 años con un canino permanente incluido en el maxilar superior, un quiste odontogénico calcificante asociado a un odontoma. Radiológicamente mostró una lesión radiotransparente, unilocular, bien definida, una masa radioopaca en su interior y el 13 incluido. El tratamiento fue la extirpación quirúrgica con anestesia local.

Casap y cols. ${ }^{31}$ describieron la aplicación de un sistema informático para la planificación y tratamiento de implantes en un paciente, dos años después de la escisión de un mixoma odontogénico mandibular izquierdo. Se colocaron 3 implantes y fue rehabilitado mediante prótesis fija. Un año después los implantes no presentaban sintomatología.

\section{Tumores no odontogénicos}

Carranza y cols. ${ }^{32}$ describieron los principios para el diagnóstico y seguimiento de las patologías oncológicas de cabeza y cuello, usando la tomografía por emisión de positrones (PET), y desarrollando otras técnicas como la tomografía computerizada de alta resolución (TCAR) y la tomografía por resonancia magnética (RM).

En un estudio retrospectivo de Aregbesola y cols. ${ }^{33}$ sobre tumores orofaciales realizado en 512 niños, tratados desde 1991 al 2001 en el Hospital Universitario de Nigeria, se encontraron 146 tumores ( $28 \%$ de los pacientes). Hubo mayor afectación en hombres que en mujeres $(1: 1,4)$ y la mayoría se dieron en la primera década de la vida. De los 146 tumores, 74 eran malignos (51\%) y 72 benignos (49\%). De los últimos, 31 fueron de los tejidos blandos y 41 de la mandíbula (20 odontogénicos y 21 no odontogénicos). Los tumores benignos más frecuentes de los tejidos blandos y de la mandíbula fueron el épulis gingival y el ameloblastoma respectivamente. De los tumores malignos 67 fueron linfomas, 5 sarcomas y 2 carcinomas.

Alvares y cols. ${ }^{34}$ presentaron un caso de osteoblastoma alrededor de un incisivo central inferior permanente incluido en un paciente de 8 años de edad, el tratamiento fue la escisión quirúrgica de la lesión y posterior tratamiento ortodóncico. Discutieron los aspectos radiológicos y microbiológicos, el diagnóstico diferencial, el tratamiento y realizaron una revisión de la literatura.

Nakayama y cols. ${ }^{35}$ determinaron la relación entre los hallazgos radiológicos de las tomografías computerizadas (TC) y las características histológicas de 10 osteosarcomas de la mandíbula. Los puntos analizados en la TC fueron los patrones de osteogénesis y los signos de destrucción ósea, y en la histología se estudió los osteoblastos, condroblastos y fibroblastos. Ocho casos fueron osteoblásticos y 2 condroblásticos. No se encontró relación estadísticamente significativa entre los hallazgos de la TC y las características histológicas de los osteosarcomas.

Chaparro y cols. ${ }^{36}$ observaron cinco casos de granuloma periférico de células gigantes en 3 hombres y 2 mujeres de edades comprendidas entre los 19 y 66 años, presentándose tres de ellos en el maxilar superior. El tratamiento consistió en la exéresis-biopsia en dos casos mediante láser de $\mathrm{CO}_{2}$ y tres con bisturí frío. No observaron ninguna recidiva en el seguimiento postoperatorio (rango de 10 meses a 4 años). El diagnóstico precoz y preciso de esta lesión permitió efectuar un tratamiento conservador sin riesgo para los dientes vecinos ni para el hueso adyacente.
Eighty-seven percent of cases were associated to delayed eruption. The region most affected was the anterior jaw. Surgical exeresis was performed in every case and the histopathologic study showed 30 cases of compound odontoma, $7 \mathrm{com}$ plex odontomas, and 2 mixed odontomas. One recurrence was found at six years.

Gallana et al. ${ }^{30}$ observed calcifying odontogenic cyst associated to odontoma in a 19-year-old patient with an impacted permanent upper canine. Radiographically, there was a well-defined radiolucent, unilocular lesion containing a radiopaque mass and impacted 13. Surgical resection was performed under local anesthesia.

Casap et al. ${ }^{31}$ described the use of a computer system for dental implant planning and treatment in a patient two years after a left mandibular odontogenic myxoma was excised. Three implants were made and rehabilitation with a fixed prosthesis was implemented. One year after implantation, the patient was asymptomatic.

\section{Non-odontogenic tumors}

Carranza et al. ${ }^{32}$ described the principles of the diagnosis and follow-up of oncologic head and neck pathology using positron emission tomography (PET) and developing other techniques like high resolution computed tomography (HRCT), and magnetic resonance tomography (MRT).

In a retrospective study by Aregbesola et al. ${ }^{33}$ of orofacial tumors in 512 children, treated from 1991 to 2001 at the Nigeria University Hospital, 146 tumors (28\% of patients) were found. Boys were affected more often than girls (1:1.4) and most of the tumors occurred in the first decade of life. Of 146 tumors, 74 were malignant (51\%) and 72 were benign (49\%). Of the benign tumors, 31 were soft-tissue tumors and 41 were of the mandible (20 odontogenic and 21 non-odontogenic). The most frequent benign tumors of the soft tissues and jaw were gingival epulis and ameloblastoma, respectively. Of the malignant tumors, 67 were lymphomas, 5 sarcomas, and 2 carcinomas.

Alvares et al. ${ }^{34}$ reported a case of osteoblastoma around an impacted permanent lower central incisor in an 8-yearold boy. The lesion was excised surgically and orthodontic therapy was given. They discussed the radiologic and microbiologic aspects, the differential diagnosis, and therapy, in addition to reviewing the literature.

Nakayama et al..$^{35}$ determined the relation between the computed tomography (CT) radiologic findings and the histologic characteristics of 10 mandibular osteosarcomas. The points analyzed in CT were patterns of osteogenesis and signs of bone destruction. Osteoblasts, chondroblasts, and fibroblasts were studied by histopathology. Eight cases were osteoblastic and 2 were chondroblastic. There was no statistically significant relation between the CT findings and the histopathologic characteristics of the osteosarcomas.

Chaparro et al. ${ }^{36}$ observed five cases of peripheral giantcell granuloma in 3 men and 2 women aged 19 to 66 years, three of them in the upper jaw. Treatment consisted of exere- 


\section{Otros tumores}

Dado los diferentes métodos terapéuticos para el cáncer de labio, Finestres y cols. ${ }^{37}$ valoraron los resultados obtenidos en 28 pacientes (17 mujeres y 11 hombres) afectos de carcinoma de labio (27 carcinomas basocelulares y 1 carcinoma escamoso) tratados mediante moldes externos de braquiterapia de alta dosis. En todos los casos se dio una remisión completa, una buena tolerancia a la terapia y ausencia de complicaciones y de recurrencias.

García y cols. ${ }^{38}$ determinaron la sobreexpresión de las proteínas c-erb-B2, p53, bcl-2, Ki67 y CD44varV6 y establecieron su valor pronóstico en el carcinoma epidermoide de labio. Para ello realizaron un estudio inmunohistoquímico de las proteínas en 79 carcinomas epidermoides de labio a lo largo de un periodo de 20 años. La inmunotinción fue positiva en el $75 \%$ de los casos para la proteína c-erb-B2, en el 70,6\% para p53, en el 3,8\% para bcl-2 y en el 89,9\% para CD44varV6. La expresión proteica de ki67 osciló entre $0 \%$ y $6,29 \%$. Sólo los pacientes que expresaban la molécula CD44varV6 se asociaron de forma significativa con una mayor supervivencia.

Saiz y cols. ${ }^{39}$ realizaron un estudio de 81 carcinomas orales de células escamosas con el objetivo de encontrar posibles factores pronóstico del mismo, de los cuales a 67 de ellos se les realizó citometría de flujo, excluyéndose los 14 restantes por no disponer de suficiente material histológico. Ninguna de las variables citométricas estudiadas (proliferación celular, índice mitótico) presentaron relación con la aparición de recidiva loco-regional, la metástasis a distancia ni con la supervivencia; concluyeron que estas variables no tenían valor como factor pronóstico en el carcinoma de células escamosas de la cavidad oral.

El propósito del siguiente estudio realizado por Villarroel y cols. ${ }^{40}$ fue determinar la expresión de moléculas del Complejo Mayor de Histocompatibilidad clase II y las moléculas co-estimuladoras CD40, CD80 y CD86 en queratinocitos de mucosa oral sana y derivados de carcinomas de células escamosas, usando citometría de flujo. Fue confirmado que los queratinocitos expresaban moléculas del Complejo Mayor de Histocompatibilidad clase II después de estimulación con IFN in vitro. Todas las líneas celulares expresaron CD40, por el contrario, CD80 y CD86 fueron negativos. La ausencia de estas últimas moléculas podría haber sido la causa por la cual los carcinomas orales escaparon de la vigilancia inmunológica y pudieron crecer, invadir y metastatizar pese al sistema inmunológico.

Ito y cols. ${ }^{41}$ realizaron un estudio retrospectivo sobre 496 tumores de las glándulas salivares desde 1972 hasta el 2001 en la población brasileña. Hubo mayor afectación en mujeres $(58,5 \%)$ que en hombres $(52,2 \%)$ y la mayoría se dieron en la edad adulta (40-50 años). De todos los casos, 161 eran malignos y 335 benignos. La mayoría de los casos se dieron en la glándula parotídea $(67,7 \%)$, seguido de las glándulas salivares menores $(22,8 \%)$ y glándula submandibulares $(9,5 \%)$. El adenoma pleomorfo fue el tumor más frecuente $(54,2 \%)$, seguido del carcinoma mucoepidermoide (13.5\%), del tumor de Warthin's $(8,5 \%)$ y del carcinoma quístico adenoide (7,9\%).

De igual manera Toida y cols. ${ }^{42}$ realizaron un estudio retrospectivo de 82 tumores de las glándulas salivares menores intraora- sis-biopsy, in two cases by $\mathrm{CO}_{2}$ laser and in three cases by cryocautery. They did not observe any recurrence in the postoperative follow-up (range 10 months to 4 years). Early and exact diagnosis of this lesion allowed conservative therapy without risk to neighboring teeth or adjacent bone.

\section{Other tumors}

Given the different therapeutic methods for lip cancer, Finestres et al. ${ }^{37}$ assessed the results obtained in 28 patients (17 women and 11 men) with carcinoma of the lip (27 basalcell carcinomas and 1 squamous-cell carcinoma) treated using brachytherapy high-dose rate surface molds. In every case, complete remission was achieved with good therapeutic tolerance and no complications or recurrences.

García et al. ${ }^{38}$ assessed the overexpression of c-erb-B2, p53, bcl-2, Ki67, and CD44varV6 proteins and established its prognostic value in squamous-cell carcinoma of the lip. They made an immunohistochemical study of the proteins in 79 squamous-cell carcinomas of the lip over a period of 20 years. Immunostaining was positive for c-erb-B2 protein in $75 \%$ of cases, for p53 in $70.6 \%$, bcl-2 in 3.8\%, and CD44varv6 in $89.9 \%$. The protein expression of ki67 ranged from $0 \%$ to $6.29 \%$. Only the patients who expressed CD44varV6 molecule showed a significant association with longer survival.

Saiz et al. ${ }^{39}$ studied 81 oral squamous-cell carcinomas in search of possible prognostic factors; flow cytometry was performed in 67, but the remaining 14 were excluded due to the lack of sufficient histologic material. None of the cytometric variables studied (cellular proliferation, mitotic index) showed a relation with local or regional recurrence, distant metastasis, or survival. They concluded that these variables had no value as prognostic factors in squamous-cell carcinoma of the oral cavity.

The purpose of the study by Villarroel et al. ${ }^{40}$ was to determine, using flow cytometry, the expression of major histocompatibility complex class II molecules and the co-stimulant molecules CD40, CD80, and CD86 in keratinocytes from healthy oral mucosa and from squamous-cell carcinomas. It was confirmed that keratinocytes expressed human major histocompatibility complex class II molecules after IFN stimulation in vitro. All the cell lines expressed CD40, but CD80 and CD86 were negative. The absence of CD80 and CD86 could explain why the oral carcinomas escaped immunologic monitoring and could grow, invade, and metastasize despite the immune system.

Ito et al. ${ }^{41}$ made a retrospective study of 496 tumors of the salivary glands from 1972 to 2001 in the Brazilian population. Women were involved more often (58.5\%) than men (52.2\%) and the majority occurred in the adult age (40-50 years). One hundred sixty-one of all cases were malignant and 335 were benign. Most of the cases occurred in the parotid gland (67.7\%), followed by the minor salivary glands (22.8\%) and submandibular glands (9.5\%). Pleomorphic adenoma was the most frequent tumor (54.2\%), 
les: 55 benignos y 27 malignos. Hubo mayor afectación en hombres que en mujeres (1:1.9). Los tumores afectaron el paladar $(n=64)$, la región vestibular $(n=10)$, el labio superior $(n=6)$, el suelo de la boca $(n=1)$ y la región retromolar $(n=1)$. Histológiacamente los tumores fueron clasificados como adenoma pleomorfo $(n=54)$, carcinoma quístico adenoide $(n=10)$, carcinoma mucoepidermoide $(n=8)$, carcinoma de células acínicas $(n=3)$, adenocarcinoma $(n=2)$, adenocarcinoma de células basales $(n=1)$, adenocarcinoma pleomórfico $(n=2)$, cistoadenocarcinoma $(n=1)$.

Prieto y cols. ${ }^{43}$ presentaron las características citopatológicas del carcinoma acinar en 4 pacientes, a los que diagnosticaron mediante PAAF tumoraciones localizadas en territorio parotídeo y a nivel laterocervical. Las extensiones citológicas mostraron abundante celularidad tumoral, núcleos desnudos en el fondo de los frotis, y ausencia de grasa y de epitelio ductal.

González y cols., ${ }^{44}$ y Sánchez y cols. ${ }^{45}$ presentaron dos pacientes diagnosticados de adenocarcinoma de origen abdominal y esofágico con metástasis en el hueso maxilar. Las lesiones intraorales eran asintomáticas y de crecimiento rápido. Valorando el mal pronóstico de las lesiones, optaron por un tratamiento sintomático, consiguiendo una adecuada calidad de vida.

González y cols. ${ }^{46}$ presentaron un inusual caso de adenocarcinoma polimorfo de bajo grado en estadio IV localizado en la fosa nasal con extensión hacia región pterigoidea. El tumor primario fue tratado mediante resección a través de una osteotomía de maxilar superior tipo Lefort I y a nivel cervical se realizó un vaciamiento ganglionar cervical supraomohioideo homolateral. Posteriormente recibió tratamiento coadyuvante con radioterapia postoperatoria y tras dos años de seguimiento no presentó recidiva.

\section{Infecciones de los maxilares}

Las infecciones de los maxilares constituyen uno de los cuadros más variados y complejos dentro de las patologías infecciosas, por ello Suei y cols. ${ }^{47}$ propusieron una clasificación para las osteomielitis mandibulares que dividieron en: osteomielitis bacteriana y osteomielitis asociada con sinovitis, acne, pústulas, hiperostosis y síndrome de la osteítis. El criterio diagnóstico para las osteomielitis bacteriana fueron la supuración y los cambios osteolíticos, las lesiones se trataron con antibióticos.

Ebihara y cols. ${ }^{48}$ presentaron el caso de un hombre de 30 años que padeció una osteomielitis de Garré tras la endodoncia del segundo molar mandibular derecho, sin infección previa. Fue diagnosticada mediante tomografía computerizada e imágenes 3D. Se realizó la reendodoncia y no hubo recurrencias a los 10 meses del tratamiento.

Ramírez y cols. ${ }^{49}$ presentaron un paciente con VIH/SIDA que 4 años antes fue tratado de tuberculosis ganglionar. Presentaba una úlcera lingual y el estudio histopatológico mostró inflamación granulomatosa crónica con células gigantes multinucleadas sugestivas de infección por micobacteria. Ante una posible recurrencia de tuberculosis, se indicaron rifampicina, pirazinamida, etambutol y estreptomicina. La lesión lingual evolucionó favorablemente, con cicatrización parcial a la primera semana y remisión total a los 45 días del inicio del tratamiento; a los 7 meses de seguimiento permaneció sin recidiva. El caso tuvo la particularidad de que la úlce- followed by mucoepidermoid carcinoma (13.5\%), Warthin's tumor (8.5\%), and adenoid cystic carcinoma (7.9\%).

Toida et al. ${ }^{42}$ also made a retrospective study of 82 tumors of the intraoral minor salivary glands: 55 benign and 27 malignant. Men were affected more often than women (1:1.9). The tumors affected the palate $(n=64)$, vestibular region $(n=10)$, upper lip $(n=6)$, mouth floor $(n=1)$, and retromolar region $(n=1)$. Histologically, the tumors were classified as pleomorphic adenoma $(n=54)$, adenoid cystic carcinoma $(n=10)$, mucoepidermoid carcinoma $(n=8)$, acinarcell carcinoma $(n=3)$, adenocarcinoma $(n=2)$, basal-cell adenocarcinoma $(n=1)$, pleomorphic adenocarcinoma $(n=2)$, and cystoadenocarcinoma $(n=1)$.

Prieto et al. ${ }^{43}$ described the cytopathologic characteristics of acinar carcinoma in 4 patients who were diagnosed of tumors of the parotid and laterocervical territory by fineneedle puncture biopsy. Cytological smears revealed abundant tumoral cellularity, bare nuclei on the background of the smears, and absence of ductal fat and epithelium.

González et al. ${ }^{44}$ and Sánchez et al. ${ }^{45}$ reported two patients diagnosed of adenocarcinoma of abdominal and esophageal origin with metastasis in the maxillary bone. The intraoral lesions were asymptomatic and rapidly growing. In view of the poor prognosis of the lesions, they decided on symptomatic treatment, which allowed an acceptable quality of life.

González et al. ${ }^{46}$ presented an unusual case of stage IV low-grade polymorphic adenocarcinoma located in the nasal cavity with pterygoid extension. The primary tumor was treated by resection through a Lefort I type osteotomy of the maxilla. In the neck, same-side supraomohyoid cervical lymph node dissection was performed. The patient later received coadjuvant treatment with postoperative irradiation. In two years of follow-up, there has been no recurrence.

\section{Jaw infections}

Jaw infections are one of the most varied and complex conditions among infectious pathologies. Suei et al. ${ }^{47}$ proposed a classification of mandibular osteomyelitis that differentiated: bacterial osteomyelitis and osteomyelitis associated with synovitis, acne, pustules, hyperostosis, and osteitis syndrome. The diagnostic criterion for bacterial osteomyelitis was suppuration and osteolytic changes; lesions were treated with antibiotics.

Ebihara et al..$^{48}$ reported the case of a 30-year-old man who suffered Garrés osteomyelitis after root canal of the right mandibular second molar without previous infection. It was diagnosed by computed tomography and three-dimensional imaging. The root canal was repeated and there were no recurrences in the 10 months after treatment.

Ramirez et al. ${ }^{49}$ presented a patient with HIV/AIDS who had been treated for nodular tuberculosis 4 years earlier. The patient had a lingual ulcer and the histopathologic study revealed chronic granulomatous inflammation and multinucleated giant cells suggestive of mycobacterial infection. 
ra lingual fue la única manifestación de infección por micobacteria, sugestiva de tuberculosis, en un paciente con VIH/SIDA.

Torres y cols. ${ }^{50}$ revisaron la literatura de la alveolitis seca, estudiando las formas de aparición clínica, los factores de riesgo y las teorías etiopatogénicas. También se examinaron las pautas utilizadas actualmente en su tratamiento y analizaron los distintos fármacos utilizados, criticando los resultados obtenidos.

\section{Cirugía periapical}

Von Arx. ${ }^{51}$ realizó una revisión de las indicaciones y limitaciones de la cirugía periapical; la selección del caso y la exploración clínica y radiográfica fueron los parámetros más importantes en la consecución del éxito; concluyó que el uso de microinstrumentos, iluminación y magnificación, simplificaban la sistemática de trabajo y permitían porcentajes de éxito elevados para esta técnica. Consideró una opción válida, las técnicas de regeneración como complemento en estas intervenciones.

Tsesis y cols..$^{52}$ compararon la sintomatología postoperatoria en cirugía periapical realizada entre la técnica clásica de resección radicular en bisel de $45^{\circ}$, con preparación de la cavidad retrógrada con instrumentos convencionales, y la realizada con microscopio, bisel mínimo y cavidad retrógrada con ultrasonidos. Respecto a la calidad de vida, en la técnica con microscopio hubo menor dolor, pero mayores dificultades postoperatorias para la apertura oral, masticación y habla.

Martí y cols. ${ }^{53}$ en 71 dientes con 100 conductos tratados con cirugía periapical, mediante ultrasonidos y obturación retrógrada con amalgama de plata, realizaron un seguimiento de 1 año, evaluando la evolución a los 6 y 12 meses; estudiaron el éxito a corto plazo en relación con el tamaño de la lesión, la resección apical y las dimensiones de la caja de obturación retrógrada. El éxito global (definido por Von Arx) a los 12 meses fue de 84,2\%, y no encontraron relación entre el éxito y el tamaño de la lesión periapical, la cantidad de ápice resecado o el tamaño de la obturación retrógada.

Taschieri y cols., ${ }^{54}$ en un estudio prospectivo de 50 dientes en 34 pacientes, con un año de seguimiento, evaluaron el éxito de las preparaciones periapicales realizadas con ultrasonidos, en relación con el tipo de diente y su localización, presencia de postes radiculares y tipo de punta ultrasónica utilizada; en los 46 dientes incluidos en el estudio, encontraron $91,3 \%$ de dientes con curación completa, un diente con dudosa curación, y 3 fracasos, no obteniendo relación estadísticamente significativa con el resto de variables estudiadas.

Respecto a los materiales de obturación en cirugía periapical, se realizó un estudio en perros, acerca de la respuesta del tejido periapical y la regeneración del cemento radicular. Se analizaron tres de los materiales más usados para obturación retrógrada (amalgama, super-EBA y MTA); hubo menor inflamación del tejido periapical en los dientes obturados con MTA y super-EBA, que en los obturados con amalgama de plata. La neoformación de cemento sólo ocurrió con el MTA, esto lo situó como el mejor material de los tres presentados, seguido del super-EBA que tuvo mejor sellado marginal que la amalgama. ${ }^{55}$

Se realizó un estudio en humanos, ${ }^{56}$ para evaluar la capacidad de sellado marginal de 3 materiales de obturación retrógrada, Super-
Due to the possible recurrence of tuberculosis, rifampicin, pyrazinamide, ethambutol, and streptomycin were prescribed. The lingual lesion evolved favorably, with partial healing the first week and total remission at 45 days of starting treatment. At 7 months of follow-up, the patient was recurrencefree. The case had the particularity that the lingual ulcer was the only manifestation of tuberculosis-like mycobacterial infection in a patient with HIV/AIDS.

Torres et al. ${ }^{50}$ reviewed the literature on alveolar osteitis, studying the forms of clinical occurrence, risk factors, and etiopathogenic theories. The guidelines currently used in the treatment of alveolar osteitis were examined and the drug options used were analyzed; the authors criticized the results obtained.

\section{Periapical surgery}

Von $A r x^{51}$ reviewed the indications and limitations of periapical surgery. Case selection and the clinical and radiographic examination were the most important parameters for success. The author concluded that the use of microinstruments, illumination, and magnification simplified the systematics of work and made it possible to achieve high success rates with this technique. Regeneration techniques were considered a valid option as a complement to these interventions.

Tsesis et al.52 compared the postoperative symptoms in periapical surgery performed using the classic $45^{\circ}$ beveled radicular resection technique with retrograde cavity preparation with conventional instruments and performed using a microscopic technique with a minimum bevel and retrograde cavity preparation with ultrasound. With respect to quality of life, the microscopic technique was accompanied by less pain, but more postoperative difficulties for opening the mouth, mastication, and speech.

Marti et al.,53 in 71 teeth with 100 root ends treated by ultrasonographic periapical surgery and retrograde silveramalgam filling, conducted a 1 -year follow-up, evaluating the evolution at 6 and 12 months. They studied the shortterm success in relation to the size of the lesion, apical resection, and the dimensions of the retrograde filling. The overall success rate (defined by Von Arx) at 12 months was $84.2 \%$. No relation was found between success and the size of the periapical lesion, the amount of apex resected, or the retrograde filling volume.

Taschieri et al., ${ }^{54}$ in a prospective study of 50 teeth in 34 patients with one year of follow-up, evaluated the success of periapical preparation with ultrasound in relation to the type of tooth and its location, presence of radicular posts, and the type of ultrasound tip used. In the 46 teeth included in the study, they found $91.3 \%$ of teeth with complete healing, one tooth with dubious healing, and 3 failures. No statistically significant relation was found with the other study variables.

With regard to the filling materials used in periapical surgery, a study was made in dogs of the periapical tissue 
EBA, IRM y Pro Root MTA; se hicieron 3 grupos de 27 raíces de caninos cada uno. No encontraron diferencias entre el super-EBA e IRM, pero el MTA proporcionó menores tasas de micro filtración.

En un estudio intraoperatorio, Von Arx, ${ }^{57}$ analizó la presencia de istmos a nivel de la resección radicular en 124 raíces de 56 primeros molares mandibulares y 32 maxilares, sometidos a cirugía periapical. Examinaron los cortes radiculares con un endoscopio encontrando que, el $76 \%$ de las raíces mesiovestibulares de los primeros molares maxilares, tuvieron dos canales y un istmo, el 10\% tenían dos canales pero no istmos y el $14 \%$ poseían un solo canal; en todas las raíces distovestibulares y palatinas había un solo canal. En los primeros molares mandibulares, el $83 \%$ de las raíces mesiales tenían dos canales con un istmo, en el $11 \%$ de los casos hallaron dos canales y ningún istmo y el $6 \%$ tenían un solo canal; el $64 \%$ de las raíces distales presentaban un solo canal y el $39 \%$ dos canales con un istmo.

La introducción de microcirugía y ultrasonidos para conformar la caja de obturación retrógrada, dan lugar a intervenciones mucho menos traumáticas, por esto, Velvart y cols. ${ }^{58}$ propusieron un exhaustivo estudio preoperatorio del tejido a manipular, diseño y manejo del colgajo mínimamente traumático y suturas sin tensión con hilo atraumático no reabsorbibles, insistiendo en que ante tales avances, era imprescindible el manejo de los tejidos blandos de forma atraumática, para un resultado libre de cicatrices.

Gagliani y cols. ${ }^{59}$ estudiaron el retratamiento quirúrgico de dientes previamente sometidos a cirugía periapical, realizando un seguimiento de 5 años de 231 raíces con lesiones periapicales; 162 raíces habían recibido tratamiento convencional de conductos sin éxito y 69 fueron tratadas previamente con cirugía periapical. A los 5 años, el $86 \%$ del primer grupo cicatrizaron completamente con evidencias radiográficas de éxito, el $7 \%$ se consideró que no tuvieron una curación completa y el $6 \%$ fracasaron. En el grupo en el que ya se había realizado cirugía periapical previa, el 59\% curaron por completo, mientras que el $17 \%$ se consideraron como curación incompleta y el $23 \%$ fracasaron. Concluyeron que el retratamiento quirúrgico, es una alternativa válida previa a la extracción, pero hay mayor tasa de fracasos cuando el diente ya ha sido intervenido.

Mead y cols. ${ }^{60}$ revisaron la literatura con el fin de evaluar los estudios que determinaban el éxito y fracasos en cirugía periapical desde el año 1970. Analizaron 70 estudios clínicos a los que se les asignó para su evaluación, una tasa del 1 al 5 según su nivel de evidencia. Encontraron que muy pocos estudios comparaban el éxito del tratamiento quirúrgico con el retratamiento no quirúrgico, pero que aun así, los resultados demostraron que la cirugía periapical era efectiva para salvar dientes naturales.

Lindeboom y cols. ${ }^{61}$ evaluaron la administración de clindamicina como profiláctico de las infecciones tras cirugía periapical. Realizaron un estudio prospectivo a doble ciego en 256 pacientes, comparando un grupo que tomó $600 \mathrm{mg}$ de clindamicina una hora antes de la intervención con un grupo control al que se le administró placebo; fueron controlados por un periodo de 4 semanas y no se encontraron diferencias estadísticamente significativas en cuanto a la presencia de infecciones entre los dos grupos. response and regeneration of the radicular cement. Three of the materials most used for retrograde filling were analyzed (amalgam, super-EBA and MTA). There was less inflammation of the periapical tissue in teeth filled with MTA and super-EBA MTA than in teeth filled with silver amalgam. Cement neoformation only occurred with MTA, which made it the best material of the three presented, followed by super$E B A$, which produced better marginal sealing than amalgam. ${ }^{55}$

A study was mades6 in humans to evaluate the marginal sealing capacity of 3 retrograde filling materials, super-EBA, IRM and Pro Root MTA. Three groups of 27 canine roots each were examined. No differences were found between super-EBA and IRM, but MTA had the lowest microfiltration rate.

In an intraoperative study, Von Arx ${ }^{57}$ analyzed the presence of an isthmus at the level of the radicular resection in 124 roots of 56 lower first molars and 32 upper first molars in which periapical surgery was performed. The author examined root sections by endoscopy, finding that $76 \%$ of the mesiovestibular roots of the upper first molars had two canals and an isthmus, $10 \%$ had two canals but no isthmus, and $14 \%$ had only one canal. All the distovestibular and palatal roots had only one canal. In the mandibular first molars, $83 \%$ of the mesial roots had two canals with an isthmus, $11 \%$ had two canals and no isthmus, and $6 \%$ had a single canal; $64 \%$ of the distal roots had a single canal and $39 \%$ had two canals and an isthmus.

The introduction of microsurgery and ultrasound to form the retrograde filling space greatly reduces the trauma of the intervention. Therefore, Velvart et al. ${ }^{58}$ proposed an exhaustive preoperative study of the tissue to be handled, the design and management of a minimally traumatic flap, and tension-free sutures with nonresorbible atraumatic thread, insisting that such advances make atraumatic management of soft tissues possible, and that this is essential for scar-free results.

Gagliani et al. ${ }^{59}$ studied the surgical retreatment of teeth after periapical surgery. In a 5-year follow-up of 231 roots with periapical lesions, 162 roots had received conventional pulp canal treatment without success and 69 roots were treated previously with periapical surgery. At 5 years, $86 \%$ of the conventional pulp canal treatment group healed completely and exhibited radiographic evidence of success, whereas $7 \%$ did not heal completely and $6 \%$ failed. In the group or previous periapical surgery, $59 \%$ healed completely, $17 \%$ healed incompletely, and 23\% failed. They concluded that surgical retreatment is a valid prior alternative to extraction, but it has a higher failure rate when the tooth has been intervened previously.

Mead et al. ${ }^{60}$ reviewed the literature to evaluate studies that assessed success or failure in periapical surgery from 1970. They analyzed 70 clinical studies to which they assigned a score of 1 to 5 to the level of evidence for purposes of evaluation. They found that very few studies com- 


\section{Patología del tercer molar}

Susarla y cols. ${ }^{62}$ estimaron los factores subjetivos y objetivos relacionados con la dificultad de extracción del tercer molar; realizaron un estudio de cohortes, en el que participaron 14 cirujanos y se incluyeron 450 extracciones de cordales en 150 pacientes, encontrando que: la localización del molar en la arcada, la anatomía del mismo, la clasificación de Winter, el número de dientes a extraer en una misma cirugía, el tipo de procedimiento y la experiencia del operador eran los factores que se relacionaban con la complejidad.

Susarla y cols. ${ }^{63}$ presentaron otro estudio cuyo objetivo fue estimar la relación entre la habilidad quirúrgica del operador para la extracción del terceros molares complicados y los posibles errores como consecuencia de la dificultad de la intervención; determinaron, que la estimación de la dificultad, es susceptible a variables que pueden llevarnos a cometer errores; estas variables pueden ser demográficas como: edad, sexo, raza; factores anatómicos como: flexibilidad de la mejilla, apertura oral; los factores menos relacionados con errores del cálculo de la dificultad son: las variaciones radiográficas y la experiencia quirúrgica del operador.

Mc Ardle y cols. ${ }^{64}$ evaluaron 100 pacientes con 122 molares mandibulares extraídos que causaban caries en cervical del $2^{\circ}$ molar; el $82 \%$ tenían una angulación entre $40^{\circ}$ y $80^{\circ}$, observando que cuando la posición era mesioangulada y aumentaba la edad del individuo, había mayor tendencia a cariar el segundo molar. Concluyeron que la extracción profiláctica de los terceros molares mesioangulados ayudaría a proteger al segundo molar de posibles lesiones.

Dodson, ${ }^{65}$ realizó un estudio en pacientes con riesgo de sufrir defecto periodontal a distal del segundo molar, tras la extracción del tercer molar, bien por la edad (mayor ó igual a 26 años), la posi-

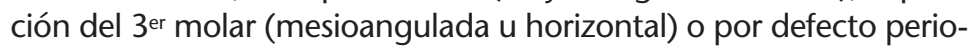
dontal preexistente a nivel distal del $2^{\circ}$ molar. Después de la extracción, se realizó regeneración ósea con hueso en polvo desmineralizado en un grupo, en otro regeneración tisular guiada y en el último no se hizo nada. Después de 26 semanas de seguimiento, el grupo con mejores resultados fueron los tratados mediante regeneración ósea con hueso en polvo desmineralizado en el momento de la extracción del tercer molar.

Sammartino y cols. ${ }^{66}$ analizaron en 18 pacientes de entre 21-26 años, la efectividad del plasma rico en plaquetas (PRP), para inducir la regeneración ósea en los defectos periodontales creados a distal del segundo molar inferior, tras la extracción de terceros molares mesioangulados. Se realizó un seguimiento de 12 meses, observando en cada control, la formación de tejido óseo en tales defectos.

Gomes y cols. ${ }^{67}$ realizaron un estudio para evaluar la frecuencia, el tipo, y los factores de riesgo asociados a las lesiones del nervio lingual durante las extracciones de $3^{\circ}$ molares cuando se realizaban colgajos de retracción por lingual. En 55 pacientes con terceros molares incluidos bilateralmente, se realizaron, extracciones con colgajo lingual en un lado y sin él en el otro lado. Hubo lesión del nervio lingual en el 9,1\% de las extracciones con colgajo de retracción lingual y no hubo ningún caso cuando no se hizo colgajo por lingual. La realización de un colgajo de retracción lingual durante la cirugía de cordales inferiores, supuso un factor de riesgo importante en cuanto a la lesión del nervio lingual. pared the success of surgical treatment with nonsurgical retreatment, but the results still demonstrated that periapical surgery was effective in saving natural teeth.

Lindeboom et al. ${ }^{61}$ evaluated the administration of clindamycin in the prophylaxis of infection after periapical surgery. They made a double-blind prospective study of 256 patients, comparing a group that took $600 \mathrm{mg}$ of clindamycin one hour before the intervention to a control group that took placebo. Patients were controlled for a period of 4 weeks and no statistically significant differences were found in the occurrence of infections between groups.

\section{Third molar pathology}

Susarla et al.62 estimated the subjective and objective factors related to the difficulty of removing the third molar. They made a cohort study in which 14 surgeons participated and 450 third-molar extractions in 150 patients were included. They found that the location of molar in the dental arcade, molar anatomy, Winter classification, number of teeth removed in a single intervention, type of procedure, and the operator's experience were the factors related to complexity.

Susarla et al. ${ }^{3}$ presented another study made to estimate the relation between the operator's surgical skill in extracting complicated third molars and possible errors as a result of the difficulty of the intervention. They found that estimation of the difficulty is susceptible to variables that can lead to errors. These variables can be demographic, like age, sex, and race; or anatomic, like cheek flexibility and mouth opening. The factors least related to errors in calculating the difficulty are radiographic variations and the operator's surgical experience.

Mc Ardle et al. ${ }^{64}$ evaluated 100 patients with 122 mandibular molars extracted that caused cervical decay in the second molar; $82 \%$ were angled $40^{\circ}$ to $80^{\circ}$. When the molar was mesially angled, as age increased there was a greater tendency to second molar decay. They concluded that prophylactic removal of mesially angled third molars helps to protect the second molar from possible lesions.

Dodson ${ }^{65}$ made a study in patients at risk of suffering a distal periodontal defect of the second molar after extraction of the third molar due to age (26 years old or older), third-molar position (mesially angled or horizontal), or a preexisting distal periodontal defect of the second molar. After extraction, bone regeneration with demineralized bone powder was performed in one group, guided tissue regeneration in another, and nothing in the last group. After 26 weeks of follow-up, the group with better results was the one treated by bone regeneration with demineralized bone powder when the third molar was extracted.

Sammartino et al. ${ }^{66}$ analyzed, in 18 patients aged 21 26 years, the effectiveness of platelet-rich plasma (PRP) in inducing bone regeneration in distal periodontal defects created in the lower second molar, after the extraction of mesially angled third molars. Patients were followed up for 12 
Robert y cols. ${ }^{68}$ destacaron el alto porcentaje de lesiones nerviosas, tanto temporales como permanentes, que se produjeron durante la extracción de terceros molares inferiores. En 535 intervenciones referidas por los miembros de la asociación de California de cirugía oral y maxilofacial, el $94,5 \%$ de los operadores obtuvieron algún caso de lesión en el nervio alveolar inferior en un periodo de 12 meses el 53\% de los casos eran en el nervio lingual; el $78 \%$ de los operadores reportaron casos de lesiones nerviosas permanentes, de estas el $46 \%$ fueron en el nervio lingual. Su conclusión fue que prevalecían las lesiones en el nervio alveolar inferior sobre las del nervio lingual; las causas más frecuentes radicaron en la inexperiencia del cirujano, una mala técnica y errores diagnósticos derivados de falsas imágenes radiográficas.

Se realizó un estudio retrospectivo, ${ }^{69}$ para analizar la evolución de las lesiones en el nervio alveolar inferior tras la extracción de terceros molares inferiores; de 4.995 extracciones, 55 (1,1\%) tuvieron lesión del nervio alveolar inferior; en los casos de lesión, lo más frecuente fue la recuperación de la sensibilidad antes de tres meses, el $50 \%$ mostraron curación completa antes de los seis meses y en algunos casos, el restablecimiento completo tardo al menos un año; la investigación mostró que la edad fue un factor de riesgo, para que las lesiones en nervio alveolar inferior producidas durante la extracción del tercer molar inferior, se recuperasen totalmente.

En pacientes, elegidos aleatoriamente, Renton y cols. ${ }^{70}$ evaluaron el riesgo de lesión del nervio alveolar inferior incluyendo la coronectomía en el procedimiento quirúrgico; el uso de esta técnica redujo significativamente la iatrogenia sobre este nervio, sin embargo destacaron que la movilización de las raíces tras la coronectomía para su eliminación, podría ser responsable de complicaciones; para evitarlo advirtieron de la importancia en el diagnóstico radiográfico, teniendo en cuenta la relación de las raíces con la continuidad del conducto dentario.

La lesión del nervio alveolar inferior tras cirugía de cordales inferiores, es la complicación más frecuente después de osteítis alveolar y las infecciones postoperatorias. Sedaghatfar y cols. ${ }^{71}$ realizaron un estudio sobre la extracción de 423 terceros molares inferiores, evaluando el riesgo de lesión sobre el nervio alveolar inferior; hubo 24 (5,7\%) casos de lesión del nervio alveolar, basándose en la observación radiográfica, encontraron cuatro hallazgos que se asociaban claramente a las lesiones de nervio alveolar inferior: oscurecimiento de la raíz del diente, estrechamiento de la raíz del diente, interrupción de las líneas blancas del conducto y divergencia del canal.

Respecto a las complicaciones tras cirugía de cordales, Chaparro y cols. ${ }^{72}$ realizaron un estudio retrospectivo de 390 extracciones de $3^{\circ}$ molares superiores e inferiores en 173 pacientes que dividieron en tres grupos según la edad: 12-14, 15-16, 17-18 para evaluar la incidencia y tipo de complicaciones. El motivo más frecuente de extracción fue la indicación ortodóncica (40,5\%), el grupo de 17-18 años de edad fue al que más extracciones se practicaron $(62,8 \%)$. La incidencia de complicaciones postextracción fue del $15,62 \%$, ocurriendo con mayor frecuencia en molares inferiores (12,82\%); todas las complicaciones fueron leves y reversibles y el grupo de edad más afectado fue el de 15-16 años con un $19 \%$. months, observing in each control bone-tissue formation in the defects.

Gomes et al. ${ }^{67}$ made a study to evaluate the frequen$c y$, type, and risk factors associated with lingual nerve injuries incurred during third-molar extraction when lingual retraction flaps were made. In 55 patients with bilateral impacted third molars, extractions were made with a lingual flap on one side and without a lingual flap on the other side. Lingual nerve injury occurred in $9.1 \%$ of the extractions with lingual flap retraction, but no case occurred in the absence of a lingual flap. The performance of lingual flap retraction during surgery of the lower third molar was a major risk factor for lingual nerve injury.

Robert et al. ${ }^{68}$ emphasized the high rate of nerve injuries, both temporary and permanent, that occurred during the extraction of lower third molars. In 535 interventions referred by the members of the California Association of Oral and Maxillofacial Surgery, $94.5 \%$ of the operators had some case of inferior alveolar nerve injury in a 12-month period, of which 53\% were in the lingual nerve; $78 \%$ of the operators reported cases of permanent nerve injuries, of which $46 \%$ were in the lingual nerve. They concluded that injuries to the inferior alveolar nerve were prevalent over lingual nerve injuries; the most frequent causes were the surgeon's inexperience, poor technique, and diagnostic errors derived from false radiographic images.

A retrospective study was made 69 to analyze the evolution of inferior alveolar nerve injuries after lower third molar extraction. In 4995 extractions, there were 55 (1.1\%) inferior alveolar nerve injuries; in the case of injuries, the most frequent outcome was the recovery of sensitivity within three months; 50\% showed complete recovery before six months, and, in some cases, complete recovery took at least one year. The investigation showed that age was a risk factor for total recovery of inferior alveolar nerve injuries that occurred during extraction of the lower third molar.

In randomly selected patients, Renton et al. ${ }^{70}$ evaluated the risk of inferior alveolar nerve injury, including coronectomy in the surgical procedure. The use of this technique significantly reduced nerve iatrogenesis, but they emphasized that root mobilization after coronectomy for its removal could be responsible for complications. They advised of the importance of radiographic diagnosis in prevention, in view of the relation between the roots and dental canal continuity.

Injury of the inferior alveolar nerve after lower third molar surgery is the most frequent complication after alveolar osteitis and postoperative infection. Sedaghatfar et al..$^{71}$ studied the extraction of 423 lower third molars, evaluating the risk of injury to the inferior alveolar nerve. There were 24 (5.7\%) cases of alveolar nerve injury. Based on radiographic examination, four findings were associated clearly with inferior alveolar nerve injury: dental root darkening, dental root narrowing, interruption of the white lines of the canal, and divergence of the canal.

With respect to the complications of third-molar surgery, Short et al. ${ }^{72}$ made a retrospective study of 390 extractions 
Pasqualini y cols..$^{73}$ estudiaron el cierre de la herida quirúrgica para analizar que situación era más favorable durante el postoperatorio. Compararon dos grupos de 100 pacientes de iguales características, en un grupo realizaron el cierre hermético de la herida mediante la sutura completa del colgajo; en el otro grupo permitieron el cierre de la herida por segunda intención tras extirpar 5-6 $\mathrm{mm}$ de mucosa. Evaluaron dolor e inflamación durante una semana, encontrando que a igual dificultad quirúrgica, hubo menor dolor e inflamación en heridas de cierre secundario mejorando el postoperatorio.

Figuereido y cols. ${ }^{74}$ realizaron un estudio de infecciones de comienzo tardío en las extracciones de 958 terceros molares inferiores; observaron después de retirar la sutura un 1,5\% de infecciones de la herida quirúrgica, lo que se acerca a otros estudios de naturaleza similar. Las infecciones producidas se desarrollaron en general a las 3-5 semanas después de la cirugía y la mitad de los casos presentaba radiotransparencia alrededor de la corona, en la mayoría de los casos hubo odontosección (13/14) y osteotomía $(11 / 14)$.

Con respecto a la medicación en cirugía de extracción del tercer molar, Esen y cols. ${ }^{75}$ encontraron resultados satisfactorios usando Remifentanil en combinación con Midazolam durante la intervención, eliminando el dolor y proporcionando un nivel de sedación aceptable.

Se comparó la eficacia del Robecoxib en el control del dolor posquirúrgico del tercer molar, administrando preoperatoriamente 50 $\mathrm{mg}$ de Robecoxib, $400 \mathrm{mg}$ de Ibuprofeno y placebo. El Robecoxib proporcionó una analgesia apreciable en el alivio del dolor las primeras seis horas tras la exodoncia; redujo el consumo de analgésicos durante las primeras 12 horas al compararlo con el lbuprofeno y el placebo. ${ }^{76}$

\section{Inclusiones dentarias}

García y cols. ${ }^{77}$ presentaron un caso de reubicación quirúrgica de segundos molares inferiores impactados, sin la extracción del germen del tercer molar, con resultado exitoso. Estudiaron las distintas posibilidades terapéuticas, según el tipo de retención y la causa.

Lewis y cols., ${ }^{78}$ presentaron dos casos de transposición de caninos para sustituir los incisivos que se encontraban incluidos. Extrajeron quirúrgicamente el incisivo central izquierdo, traccionaron el canino y colocaron una corona Veneer para conseguir la apariencia de un incisivo central superior.

Kofod y cols. ${ }^{79}$ trataron un caso de anquilosis de un incisivo central superior que había sido reimplantado tras un trauma; aprovechando la anquilosis, el incisivo fue utilizado para anclaje y distalización de la dentición maxilar, posteriormente, se eliminó la porción apical de la raíz anquilosada y se traccionó hasta su posición final.

Bayrak y cols., ${ }^{80}$ aportaron un caso en el que discutieron la necesidad de tomografía computerizada en el diagnóstico de supernumerarios situados por palatino de incisivos centrales permanentes, para descartar la relación de éstos con las raíces de los incisivos. Concluyeron que la tomografía computerizada ofrecía una información más completa; sin embargo, la radiación a la que se of upper and lower third molars in 173 patients, who were divided into three age groups: $12-14,15-16$, and 17-18 years, to evaluate the incidence and type of complications. The most frequent reason for extraction was an orthodontic indication (40.5\%); the 17-18 year old age group had the largest number of extractions (62.8\%). The incidence of postextraction complications was $15.62 \%$, which occurred most frequently in lower molars (12.82\%). All the complications were mild and reversible and the age group most affected was the 15-16 year old group, with 19\%.

Pasqualini et al. ${ }^{73}$ studied the closure of the surgical wound to analyze which situation was more favorable during the postoperative period. They compared two groups of 100 patients of the same characteristics, in which the wound was closed by complete flap suture in one group and the wound was closed in a second attempt after removing 5-6 $\mathrm{mm}$ of mucosa in the other group. They evaluated pain and inflammation during one week, finding that in interventions of equivalent surgical difficulty, there was less pain and inflammation and a better postoperative period in the wounds closed in the second attempt.

Figuereido et al. ${ }^{74}$ made a study of delayed-onset infections in 958 lower third molar extractions; after removing the suture, they observed $1.5 \%$ of surgical wound infections, which approaches the rate of other similar studies. The infections that occurred generally developed 3-5 weeks after surgery. Half of the cases presented radiolucency around the crown; most of the cases had odontosection (13/14) and osteotomy (11/14).

With respect to medication in third-molar extraction surgery, Esen et al. ${ }^{75}$ found satisfactory results using remifentanil in combination with midazolam during the intervention, which eliminated pain and provided an acceptable level of sedation.

The effectiveness of robecoxib in the control of postoperative third molar pain was compared by preoperative administration of robecoxib $50 \mathrm{mg}$, ibuprofen $400 \mathrm{mg}$, and placebo. Robecoxib provided appreciable analgesia in the first six hours after tooth extraction; it reduced analgesic use in the first 12 hours compared with ibuprofen and placebo. ${ }^{76}$

\section{Dental impaction}

García et al. ${ }^{77}$ reported a case of successful surgical repositioning of an impacted lower second molar without extraction of the third molar germ. They studied the different therapeutic possibilities, depending on the type of retention and its cause.

Lewis et al. ${ }^{88}$ presented two cases of canine transposition to replace impacted incisors. They removed the left central incisor surgically, realigned the canine, and placed a veneer crown to replicate the appearance of an upper central incisor.

Kofod et al. ${ }^{79}$ treated a case of ankylosis of an upper central incisor that had been reimplanted after an injury. Taking advantage of the ankylosis, the incisor was used for 
exponía el paciente era mayor. La TC, estaría limitada en casos en los que la radiografía convencional, ofreciera poca información.

Shapira y cols., ${ }^{81}$ reportaron un canino impactado en palatino que migró a través de la sutura palatina hacia el otro lado del hueso maxilar. Concluyeron que la migración de caninos impactados era una entidad rara que podía ocurrir tanto en maxilar como en mandíbula, una exploración radiográfica mediante ortopantomografía sería esencial antes de un tratamiento ortodóncico para descubrir posibles migraciones del canino; cuando el canino se encontró en posición horizontal y había migrado de su posición original, el tratamiento de elección fue la extracción.

\section{Transplante y reimplante dental}

Respecto al transplante dental autólogo, en una evaluación de 182 casos, Kim y cols. ${ }^{82}$ encontraron una tasa de fracasos del $4,5 \%$. Se analizó estabilidad primaria, reabsorción radicular y anquilosis, encontrando que aquellos transplantes con buena estabilidad inicial mostraron mejor cicatrización. El tiempo medio extraoral fue de 7,58 min, no se encontró relación entre este parámetro y la reabsorción radicular.

Maia y cols. ${ }^{83}$ aportaron un incisivo central superior incluido con una curvatura radicular, se solucionó mediante el autotransplante. El emplazamiento del diente en su posición fue compleja por su forma radicular, por lo que se posicionó al revés: la zona vestibular hacia palatino para salvar la tabla vestibular que de otro modo se hubiese visto comprometido. Comentaron que aunque son muchas las técnicas utilizadas para el rescate de un diente incluido, el autotransplante era un sistema que se debería tener en cuenta a la hora de ofrecer posibilidades de tratamiento al paciente.

Han sido muchas, las técnicas definidas para estabilizar los dientes transplantados, tales como brackets ortodóncicos, ligaduras, suturas y resinas compuestas; Akkocaoglu y cols..$^{84}$ midieron la tasa de éxito en dientes auto transplantados sin estabilización. Los resultados de su estudio demostraron que el autotransplante realizado a un neoalvéolo de dimensión mesiodistal adecuada al diente a transplantar, no necesitaba fijación primaria para su estabilización, por tanto era un tratamiento seguro en los casos de pronóstico favorable de caninos impactados y terceros molares de ápices cerrados.

Según Gauss y cols. ${ }^{85}$ una ferulización rígida y prolongada, en el autotransplante de terceros molares inmaduros, tuvo una influencia negativa en el desarrollo radicular y su longitud final, especialmente cuando se trataba de un germen.

Chappuis y Von Arx., 86 siguieron durante un año la evolución de 45 avulsiones dentales reimplantadas. El éxito se taso entorno al 95,6\%, fracasaron 2 reimplantes. Hubo anquilosis en el 28,9\%, su incidencia se puso en relación al tiempo extraoral en seco. Si se mantienen las normas de endodoncia, la reabsorción radicular inflamatoria disminuye al 6,7\%.

Pohl y cols. ${ }^{87}$ realizaron un estudio sobre los resultados en reimplantes de dientes permanentes avulsionados, y escribieron tres artículos sucesivos en los que analizaron tres parámetros por separado: consideraciones endodónticas, periodontales, y análisis de supervivencia.

Respecto al transporte del diente avulsionado, Pohl y cols. ${ }^{88}$ explicaron que el mantenimiento y transporte en una solución fisioló- anchorage and distalization of the maxillary teeth. Later, the apical portion of the ankylosed root was eliminated and moved to its final position.

Bayrak et al. ${ }^{80}$ reported a case in which they discussed the need for computed tomography in the diagnosis of supernumerary teeth located palatally to the permanent central incisors to rule out a relation between the supernumeraries and the incisor roots. They concluded that computed tomography offered more complete information, but the patient's radiation exposure was greater. CT use would be restricted to cases in which conventional radiography offered little information.

Shapira et al. ${ }^{81}$ reported a canine impacted in the palatal that migrated through the palatal suture to the other side of the maxillary bone. They concluded that the migration of impacted canines is a rare condition that can occur in either the maxilla or mandible and that examination by orthopantomography is essential before orthodontic treatment to discover possible canine migration. When the canine was horizontal and had migrated from its original position, the treatment of choice was extraction.

\section{Dental transplantation and reimplantation}

With respect to autologous dental transplantation, in an evaluation of 182 cases, Kim et al..$^{82}$ found a failure rate of 4.5\%. Primary stability, radicular resorption, and ankylosis were analyzed and it was found that transplants with good initial stability healed better. The mean extraoral time was $7.58 \mathrm{~min}$; no relation was found between extraoral time and radicular resorption.

Maia et al. ${ }^{83}$ reported an impacted upper central incisor with a radicular curvature that was resolved by autotransplantation. Tooth positioning was complex due the form of the root, so it was turned around, with the vestibular face toward the palate, to conserve the vestibular plate, which would have been compromised otherwise. They commented that although many techniques are used to rescue an impacted tooth, autotransplantation is a system that should be considered when discussing treatment possibilities with the patient.

Many techniques have been described for stabilizing transplanted teeth, such as orthodontic brackets, ligatures, sutures, and resin compounds. Akkocaoglu et al. (84) measured the success rate in autotransplanted teeth without stabilization. The results of their study demonstrated that autotransplantation on a socket of suitable mesiodistal dimensions, opened for the tooth to be transplanted, did not require primary fixation for stabilization. Consequently, it was a safe treatment for cases of impacted canines and third molars with closed apexes of favorable prognosis.

According to Gauss et al., 85 prolonged rigid splinting during the autotransplantation of immature third molars had a negative influence on root development and final root length, especially when a dental germ was involved.

Chappuis and Von Arx ${ }^{86}$ followed up the evolution of 45 reimplanted avulsed teeth for one year. The success rate was 
gica, promovería la neoformación del ligamento periodontal. Para dientes mantenidos en seco o en malas condiciones, que el potencial fisiológico de reparación pudo verse alterado, señalaron que el uso de Emdogain ${ }^{\circledR}$ con glucocorticoides tópicos y doxiciclina sistémica, sería capaz de promover esa regeneración periodontal. Recomendaron a todos los lugares públicos y privados que tuvieran contacto con niños, la posesión de sistemas fisiológicos de transporte para dientes avulsionados, ya que el tiempo de exposición y el medio de transporte son de vital importancia en el éxito del reimplante.

Según Pohl y cols. ${ }^{89}$ el único factor que se relacionaba de manera significativa a la perdida de los dientes reimplantados, era la capacidad fisiológica de regeneración del ligamento periodontal. Las complicaciones producidas por el tratamiento endodóntico, fueron debidos a la madurez del diente; a diferencia de otros estudios, esto no resulto un factor predictivo en el éxito del reimplante.

Se presentó un caso, en el que se aplicó Emdogain ${ }^{\circledR}$ sobre la superficie radicular de un diente avulsionado, en la que sobrevivían muy pocas células del cemento, debido al trauma mecánico y al mantenimiento en seco. El resultado no fue bueno, de lo que se derivó que el Emdogain ${ }^{\circledR}$ no daba buenos resultados sin la existencia de un número suficiente de células del ligamento periodontal y del cemento. ${ }^{90}$

Barrett y cols. ${ }^{91}$ aplicaron Emdogain ${ }^{\circledR}$ en la superficie radicular de incisivos permanentes avulsionados en niños, y siguieron la evolución durante 32 meses. Tras analizar el resultado radiográfico y compararlo con otros estudios control, encontraron que los incisivos replantados sufrieron reabsorción radicular y anquilosis, aunque ninguno sufrió infecciones o reabsorción inflamatoria radicular, se concluyó que el Emdogain ${ }^{\circledR}$, por sí mismo no prevenía la reabsorción radicular ni promovía la regeneración del ligamento periodontal, aunque los resultados de cicatrización al compararlos con los estudios control eran significativamente mejores.

En un caso que aportaron Çaglar y cols. ${ }^{92}$ evaluaron el reimplante de un incisivo central y un incisivo lateral tratado con Emdogain ${ }^{\circledR}$. Dos minutos antes del reimplante se lavaron la superficie de la raíz y el alvéolo con una solución salina y después fueron tratados con Emdogain ${ }^{\circledR}$, se colocaron con presión digital y la ferulización semirigida fue de 10 días. Se revisó al mes a los 2, 6 y 12 meses sin que hubiese lesión inflamatoria ni reabsorción radicular.

\section{Fármacos}

La anestesia intraligamentosa con articaina al $4 \%$ y epinefrina 1:100:000, en comparación con la inyección de lidocaína 2\% y epinefrina 1:100.000, ofreció una eficacia similar en estudios realizados por Berlin y cols. ${ }^{93}$

Brkovic y cols. ${ }^{94}$ compararon clonidina y epinefrina con lidocaína, en el bloqueo del nervio alveolar inferior. La clonidina indujo la anestesia de manera más rápida, pero en la duración y en la intensidad percibida, no se encontraron diferencias entre los dos grupos. El dolor postoperatorio fue menor en el grupo de la clonidina, el número total de medicación antiálgica que tomaron los pacientes fue significativamente menor en el grupo de la clonidina.

Se analizaron la concentración de catecolaminas en sangre y la respuesta hemodinámica al vasoconstrictor, durante la inyección convencional en comparación a la técnica de Gow-Gates en el blo- about 95.6\%; 2 reimplantations failed. Ankylosis occurred in 28.9\%; its incidence was assessed in relation to extraoral dry time. If root canal guidelines are followed, inflammatory root resorption diminishes to $6.7 \%$.

Pohl et al. ${ }^{87}$ studied the outcome of the reimplantation of avulsed permanent teeth and wrote three successive articles in which they analyzed separately three parameters: endodontic and periodontal considerations, and survival analysis.

With respect to the transport of the avulsed tooth, Pohl et al. ${ }^{88}$ explained that conserving and transporting the tooth in a physiological solution helps to promote neoformation of the periodontal ligament. In the case of teeth conserved in dry or otherwise poor conditions, in which the physiologic repair potential could be altered, they indicated that the use of an enamel matrix derivative (Emdogain $\left.{ }^{\circledR}\right)$ with topical glucocorticoids and systemic doxycycline may favor periodontal regeneration. They recommended that all public and private places where children congregate be equipped with physiological systems for the transport of avulsed teeth because the exposure time and transport medium are of vital importance for the success of tooth reimplantation.

According to Pohl et al., ${ }^{89}$ the only factor significantly related to the loss of reimplanted teeth is the physiological capacity for regenerating the periodontal ligament. The complications of endodontic treatment were due to the maturity of the tooth; in this study, unlike other studies, this was not a predictive factor of successful reimplantation.

A case was reported in which an enamel matrix derivative (Emdogain ${ }^{\circledR}$ ) was applied to the root surface of an avulsed tooth, where just a few cells of the cement had survived after the injury and dry conservation conditions. The result was not good, from which it was inferred that the enamel matrix derivative did not yield good results unless a sufficient number of cells of the periodontal ligament and cement was present. .0

Barrett et al. ${ }^{91}$ applied enamel matrix derivative (Emdogain ${ }^{\circledR}$ ) to the root surface of avulsed permanent incisors in children and followed up their evolution for 32 months. After analyzing the radiographic outcome and comparing it with other controlled studies, they found that the reimplanted incisors experienced radicular resorption and ankylosis, although none exhibited root infection or inflammatory resorption. They concluded that the enamel matrix derivative (Emdogain ${ }^{\circledast}$ ) per se did not prevent root resorption or promote regeneration of the periodontal ligament, although the results of healing were significantly better when compared with those of the control studies.

In a case reported by Çaglar et al., 92 the reimplantation of a central incisor and lateral incisor treated with an enamel matrix derivative (Emdogain ${ }^{\circledast}$ ) was evaluated. Two minutes before reimplantation, they bathed the root surface and socket with saline solution and then treated it with the enamel matrix derivative. The teeth were inserted with digital pressure and a semirigid plate was used for 10 days. At 2, 6, and 12 months of follow-up, there was no inflammatory lesion or root resorption. 
queo anestésico mandibular. La concentración de epinefrina en plasma, fue mayor en la técnica convencional, mientras que no hubo diferencias significativas entre los dos grupos. Los parámetros hemodinámicas no mostraron relación con la inyección anestésica. ${ }^{95}$

Dogan y cols., ${ }^{96}$ presentaron un caso de alteración oftalmológica y síndrome de Horner en una mujer de 19 años referida por un dentista. Presentaba diplopia, miosis, enoftalmia parcial y lacrimación del ojo izquierdo, tras anestesia local intraoral para la extracción del tercer molar superior izquierdo; los síntomas aparecieron pocos segundos después de la inyección de $5 \mathrm{mg}$ de prilocaína. Los síntomas desaparecieron por completo a las 6 horas sin ningún tipo de tratamiento.

Horowitz y cols., ${ }^{97}$ presentaron tres casos de alteración oftalmológica por anestesia dental; dos con neuropatía óptica ipsilateral y uno con abducción disminuida ipsilateral, y dilatación con poca actividad en la pupila, después de anestesia local para el tratamiento de dientes superiores. En un caso la pupila no estaba dilatada, el TC cerebral y orbital no presentaron hallazgos radiológicos y recuperó la visión en dos semanas; en el segundo caso la pupila estaba dilatada, el TC no evidenció hallazgos y no recuperó la visión; en el ultimo caso la visión se recuperó en 24 horas.

\section{Otros}

Pérez y cols..$^{98}$ demostraron que se pueden realizar la mayoría de las intervenciones quirúrgicas de la cavidad bucal en la población pediátrica en un medio ambulatorio. Para ello contabilizaron la actividad quirúrgica de las unidades de cirugía bucal y cirugía con láser en la población pediátrica en el Máster de Cirugía e Implantología Bucal de la Universidad de Barcelona. De las 3.187 intervenciones quirúrgicas realizadas, 489 fueron en pacientes menores de 18 años. La exodoncia quirúrgica de terceros molares inferiores fue la más frecuente $(55,6 \%)$, seguida de otras extracciones dentarias $(33,6 \%)$, quirúrgicas o no, y del resto de intervenciones $(10,6 \%)$ que incluyeron: fenestraciones de caninos $u$ otros dientes incluídos, exéresis de frenillos, de mucoceles y reubicaciones dentarias. Se presentaron complicaciones tras la extracción quirúrgica de los terceros molares en un $15,93 \%$ de los casos, siendo las más frecuentes el dolor $(4,35 \%)$ y la tumefacción $(4,35 \%)$, signos propios de la inflamación postoperatoria.

Stübinger y cols. ${ }^{99}$ describieron un caso en el que un paciente unos días después de someterse a una extracción dental de un molar superior derecho acudió con pérdida de la visión en el ojo derecho, hinchazón dolorosa y enrojecimiento en la zona de la órbita. Observaron la existencia una infección odontógena que no fue tratada antes de la extracción, y que debido a su proximidad anatómica al seno maxilar produjo esta complicación; aconsejaron enfriar un proceso infeccioso antes de la extracción para evitar complicaciones posteriores serias.

Bagán y cols. ${ }^{100}$ presentaron 10 pacientes con lesiones de ostoradionecrosis en la mandíbula y la mitad de ellos también en el maxilar; todos habían recibido quimioterapia para el tratamiento de metástasis, 6 con cáncer de pecho y 4 con mieloma múltiple. Analizaron la localización de la metátasis, las características se la osteonecrosis y el tratamiento que habían recibido. Tras el análisis histopatológico, todas las lesiones fueron diagnosticadas de osteo-

\section{Drugs}

Intraligamentous anesthesia with articaine $4 \%$ and epinephrine 1:100,000 had an efficacy similar to an injection of lidocaine $2 \%$ and epinephrine 1:100,000 in studies by Berlin et al.. 93

Brkovic et al. ${ }^{94}$ compared clonidine and epinephrine with lidocaine in the blockade of the inferior alveolar nerve. Clonidine induced anesthesia more rapidly, but no differences between groups were found in the duration and perceived intensity of anesthesia. There was less postoperative pain in the clonidine group and the patients in the clonidine group took a significantly lower total number of analgesic medications.

Blood catecholamine concentration and hemodynamic response to the vasoconstrictor were analyzed in conventional injection compared to the Gow-Gates technique in mandibular anesthetic blockade. The plasma epinephrine concentration was higher with the conventional technique, but there were no significant differences between the two groups. The hemodynamic parameters showed no relation with the type of anesthetic injection. ${ }^{95}$

Dogan et al. ${ }^{96}$ reported a case of ophthalmologic disorder and Horner syndrome in a 19-year-old woman referred by a dentist. She presented diplopia, miosis, partial enophthalmos and lacrimation of the left eye after local intraoral anesthesia for extraction of the upper left third molar; the symptoms appeared a few seconds after the injection of prilocaine $5 \mathrm{mg}$. The symptoms disappeared completely without treatment, after 6 hours.

Horowitz et al. ${ }^{97}$ reported three cases of ophthalmologic disorder due to dental anesthesia; two with sameside optic neuropathy and one with same-side diminished abduction and pupil dilation and diminished pupil activity after local anesthesia for treatment of the upper teeth. In one case, the pupil was not dilated, cerebral and orbital CT disclosed no radiologic findings and the patient recovered sight in two weeks; in the second case, the pupil was dilated, the CT findings were negative, and the patient did not recover sight; in the last case, the patient's sight recovered in 24 hours.

\section{Other}

Pérez et al. ${ }^{98}$ demonstrated that most surgical interventions of the oral cavity in pediatric patients can be performed in the outpatient setting. They tabulated the surgical activity of the oral surgery and laser surgery units in the pediatric population of the "Master of Oral Surgery and Implantology" course of the University of Barcelona. Of 3187 operations performed, 489 were in patients younger than 18 years. Surgical extraction of the lower third molars was the most frequent intervention (55.6\%), followed by other dental extractions (33.6\%), surgical or nonsurgical. The rest of the interventions (10.6\%) included: fenestration of impacted canine or other teeth, frenulum or mucocele excision, and dental repositioning. Complications appeared after surgi- 
necrosis crónicas sin evidencias de metástasis y todos habían sido tratados con bifosfonatos. Jiménez-Soriano y Bagán ${ }^{101}$ comentaron en otro trabajo, la relación entre los bifosfonatos y la osteonecrosis, revisaron la literatura, y repasaron los puntos más interesantes acerca de este tema.

\section{Conclusión}

Aportar a otros investigadores una rápida identificación de los artículos más importantes de cirugía bucal publicados en el año 2005.

\section{Bibliografía}

1. Seong K, Byoung Y, So O, Soo M, Sam H, Je Ch. The differential expression pattern of BMP-4 between the dentigerous cyst and the odontogenic keratocyst. J Oral Pathol Med 2005;34:178-83.

2. Díaz JM, Infante P, Belmonte R, Ruiz L, García A, Gutiérrez JL. Basal cell nevus syndrome. Presentation of six cases and literature review. Med Oral Pathol Oral Cir Bucal 2005; 10:57-66.

3. Smith J, Kellman R. Dentigerous cysts presenting as head and neck infections. Otolaryngol Head Neck Surg 2005;133:715-7.

4. Edamatsu M, Kumamoto H, Ooya k, Echigo S. Apoptosis-related factors in the epithelial components of dental follicles and dentigerous cysts associated with impacted third molars of the mandible. Oral Surg Oral Med Oral Pathol Oral Radiol Endod 2005;99:17-23.

5. Kaplan I, Gal G, Anavi Y, Manor R, Calderon S. Glandular Odontogenic cyst: treatment and recurrence. J Oral Maxillofac Surg 2005:63:435-41.

6. Qin X, Li J, Chen X, Long X. The glandular odontogenic cyst: clinic pathologic features and treatment of 14 cases. J Oral Maxilofac Surg 2005;63:694-9.

7. Kaplan I, Anavi Y, Manor R, Sulkes J, Calderon S. The use of molecular markers as an aid in the diagnosis of glandular odontogenic cyst. Oral Oncol 2005;41:895-902.

8. Tanimoto K, Kakimoto N, Nishiyama H, Murakami S, Kshino M. MRI of nasoalveolar cyst: case report. Oral Surg Oral Med Oral Pathol Oral Radiol Endod 2005;99:221-4.

9. Takeda Y, Oikawa Y, Furuya I, Satoh M, Yamamoto H. Mucous and ciliated cell metaplasma in epithelial linings of odontogenic inflammatory and developmental cysts. J Oral Science 2005;2:77-81.

10. Baykul T, Saglam A, Aydin U, Basak K. Incidente of cystic changes in radiographically normal impacted lower third molar follicles. Oral Surg Oral Med Oral Pathol Oral Radiol Endod 2005;99:542-5.

11. Belmonte-Caro R, Vélez-Gutiérrez MJ, García De La Vega-Sosa FJ, García-PerlaGarcía A, Infante-Cossío PA, Díaz-Fernández JM, Torres-Carranza E. A Stafne's cavity with unusual location in the mandibular anterior area. Med Oral Patol Oral Cir Bucal 2005;10:173-9.

12. Fernández AM, Duarte EC, Pimenta FJ, Souza LN, Santos VR, Mesquita RA. Odontogenic tumors: a study of 340 cases in a Brazilian population. J Oral Pathol Med 2005;34:583-7.

13. Ladipo A, Folake O, Olugbeniga M, Lanre W, Toyin G, Olamide B, Adisa J. Odontogenic tumors: a review of 319 cases in a Nigerian teaching hospital. Oral Surg Oral Med Oral Pathol Oral Radiol Endod 2005;99:191-5.

14. Simon E, Merks M, Vuhahula E, Ngassapa D, Stoelinga P. A 4 year prospective study on epidemiology and clinicopathological presentation of odontoge- cal extraction of third molars in $15.93 \%$ of cases, the most frequent being pain (4.35\%) and swelling (4.35\%), which are signs of postoperative inflammation.

Stübinger et al. ${ }^{99}$ described a case in which a patient was seen for loss of right eyesight, painful swelling, and erythema of the orbital area days after undergoing extraction of a right upper molar. They found an odontogenic infection that had not been treated before extraction. Due to anatomical proximity with the maxillary sinus, it had produced this complication. They recommend treating infectious processes before extraction to avoid serious complications.

Bagán et al. ${ }^{100}$ reported 10 patients with osteoradionecrosis lesions of the mandible; half of them also had maxillary lesions. All had received chemotherapy for the treatment of metastases, 6 of breast cancer and 4 of multiple myeloma. They analyzed metastasis location, the characteristics of the osteonecrosis, and treatment. After histopathologic study, all the lesions were diagnosed as chronic osteonecrosis without evidence of metastasis and all were treated with bisphosphonates. Jiménez-Soriano and Bagán, 101 in another article, discussed the relation between the bisphosphonates and osteonecrosis. They reviewed the literature and some of the most interesting aspects of this topic.

\section{Conclusion}

The authors offer other researchers a quick overview of the most important articles in oral surgery published in 2005. 
nic tumors in Tanzania. Oral Surg Oral Med Oral Pathol Oral Radiol Endod 2005;99:598-602.

15. Adebayo ET, Ajike SO, Adekeye EO. A review of 318 odontogenic tumors in Kaduna, Nigeria. J Oral Maxillofac Surg 2005;63:811-9.

16. Artés $M J$, Prieto $M$, Navarro $M$, Peñas $L$, Camañas $A$, Vaquero $M C$, Vera FJ. Ameloblastoma. Diagnosis by means of FNAB. Report of two cases. Med Oral Patol Oral Cir Bucal 2005;10:205.

17. Torres D, Infante P, Hernández JM, Gutiérrez JI. Mandibular ameloblastoma. A review of the literatura and presentation of six cases. Oral Surg Oral Med Oral Pathol 2005;10:231-8.

18. Muvova L, Dilu N, Sokolo M. The treatment of choice for recurrent ameloblastoma. Odontostomal Trop 2005;28:13-8.

19. Arotiba GT, Ladeinde AL, Arotiba JT, Ajike SO, Ugboko VI, Ajayi OF. Ameloblastoma in Nigerian children and adolescents: a review of 79 cases. J Oral Maxillofac Surg 2005;63:747-51.

20. Patel H, Rees R. Unicystic ameloblastoma presenting in Gardner's Syndrome: a case report. Br Dent J 2005; 198:747-8.

21. Cunha E, Fernandes A, Versiani M, Loyola A. Unicystic ameloblastoma: a posible pitfall in periapical diagnosis. Int Endod J 2005;38:334-40.

22. Hirota M, Auki S, Kawabw R, Fujita K. Desmoplastic ameloblastoma featuring basal cell ameloblastoma: a case report. Oral Surg Oral Med Oral Pathol Oral Radiol Endod 2005;99:160-4.

23. Seim P, Regezi JA, O’Ryan F. Hybrid ameloblastoma and calcifying epithelial odontogenic tumor: a case report. J Oral Maxillofac Surg 2005;63:852-5.

24. Chen Y, Li T, Gao Y, Yu S. Ameloblastic fibroma and related lesions: a clinicopathologic study with referente to their nature and interrelationship. J Oral Pathol Med 2005;34:588-95.

25. Handschel J, Depprich R, Zimermann A, Kübler N. Adenomatoid odontogenic tumor of the mandible: review of the literature and report of a rare case. Head Face Med 2005;1:3.

26. Motamedi MH, Shafeie HA, Azizi T. Salvage of an impacted canine associated with an adenomatoid odontogenic tumour: a case report. Br Dent / 2005;23:89-90.

27. Barboza CA, Pereira PL, Freitas RA, Costa AdeL, Souza LB. Proliferating cell nuclear antigen (PCNA) and p53 protein expresion in ameloblastoma and adenomatoid odontogenic tumor. Braz Dent J 2005;16:1-10.

28. Nelson P, Silva R, Faria G, Freitas A. Odontoma-like malformation in a permanent maxillary central incisor subsequent to trauma to the incisor predecesor. Dent Traumatol 2005;21:309-12.

29. Tomizawa M, Outsuka Y, Noda T. Clinical observations of odontomas in Japanese children: 39 cases including one recurrent case. International Journal of Paediatric Dentistry 2005;15:37-43.

30. Gallana S, Mayorga F, Torres F, Avellá F, Salazar C. Calcifying odontogenic cyst associated with complex odontoma: case report and review of the literature. Med Oral Pathol Oral Cir Bucal 2005;10:2437.

31. Casap N, Wexler A, Tarazi E. Application of a surgical navigation system for implant surgery in a deficient alveolar ridge postexcision of an odontogenic myxoma. J Oral Maxillofac Surg 2005;63:982-8.

32. Carranza D, Lomeña F, Soler M, Berini L, Gay C. The diagnostic possibilities of positron emission tomography (PET): applications in oral and maxillofacial buccal oncology. Med Oral Patol Oral Cir Bucal 2005;10:331-42.
33. Aregbesola SB, Ugkobo, VI, Akinwande JA, Arole GF, Fagade OO. Orofacial tumours in suburban Nigerian children and adolescents. Br J Oral Maxillofac Surg 2005;43:226-31.

34. Alvares A, Giao M, Casati L, Negrao Fleury R, Sant'ana E. Osteoblastoma of the mandible: systematic review of the literature and report of a case. Dentomaxilofac Radiol 2005;34:1-8.

35. Nakayama E, Sugiura K, Kobayasbi I, Oobu K, Ishibashi H, Kanda $\mathrm{S}$. The association between the computed tomography findings, histologic features, and outcome of osteosarcoma of the jaw. J Oral Maxillofac Surg 2005;63:311-8.

36. Chaparro-Avendaño AV, Berini-Aytés L, Gay Escoda C. Granuloma periférico de células gigantes. A propósito de 5 casos y revisión de la literatura. Med Oral Patol Oral Cir Bucal 2005;10:48-57.

37. Finestres-Zulbeldia F, Guix Mrlcior B, Cloquell Damián A, Chimenos Küstner E, Tello Luque JL. Tratamiento del carcinoma de labio mediante braquiterapia de alta tasa de dosis. Med Oral Patol Oral Cir Bucal 2005; 10:17-24.

38. García-Montesinos B, Val J, Saiz R. Epidermoid carcinoma of the lip: an immunohistochemical study. Med Oral Patol Oral Cir Bucal 2005; 10:454-61.

39. Saiz R, Corchero G, García B, González T, Sánchez S. Oral squamous cell carcinoma, cytometric parameters of prognostic interest. Med Oral Pathol Oral Cir Bucal 2005;10:462-7.

40. Villarroel M, Speight P, Barret A. Expression of Major Histocompatibility Complex class II and costimulatory molecules in oral carcinomas in vitro. Med Oral Patol Oral Cir Bucal 2005;10:188-95.

41. Ito F, Ito K, Vargas P, Almeida P, Lopes M. Salivary gland tumors in a Brazilian population: a retrospective study of 496 cases. Int / Oral Maxillofac Surg 2005;34:533-6.

42. Toida M, Shimokawa K, Makita H, Kato K, Kobayashi A, Kusunoki Y. Intraoral minor salivary gland tumors: a clinicopathological study of 82 cases. Int J Oral Maxillofac Surg 2005;34:528-32.

43. Prieto $M$, Artés M], Navarro M, Camañas A, Vera FJ. Cytological characteristics of acinic cell carcinoma (ACC) diagnosed by fine-needle aspiration biopsy (FNAB). A study of four cases. Med Oral Patol Oral Cir Bucal 2005; 10:103-8.

44. González-Martín-Moro J, Cebrián-Carretero JL, Gómez-García E, del Castillo-Pardo de Vera JL, del Val D. Intraoral tumor with rapid growing. Report of a case. Med Oral Patol Oral Cir Bucal 2005;10:440-3.

45. Sánchez-Jiménez J, Acebal-Blanco F, Arévalo-Arévalo RE, Molina-Martínez M. Metastatic tumours in upper maxillary bone of esophageal adenocarcinoma. A case report. Med Oral Patol Oral Cir Bucal 2005; 10:252-7.

46. González-Lagunas J, Alasà-Caparrós C, Vendrell-Escofet G, Huguet-Redecilla P, Raspall-Martin G. Polymorphous low-grade adenocarcinoma of the nasal fossa. Med Oral Patol Oral Cir Bucal 2005;10:367-70.

47. Suei Y, Taguchi A, Tanimoto K. Diagnosis and classification of mandibles osteomielitis. Oral Surg Oral Med Oral Pathol Oral Radiol Endod 2005; 100:207-14.

48. Ebihara A, Yoshioka T, Suda H. Garré's osteomielitis manager by root canal treatment of a mandibular second molar: incorporation of computed tomography with 3D reconstruction in the diagnosis and monitoring of the disease. Int Endod / 2005;38:255-61.

49. Ramírez-Amador V, Anaya-Saavedra G, González-Ramírez I, Mosqueda-Gómez JL, Esquivel-Pedraza L, Reyes-Gutiérrez E, Sierra-Made- 
ro J. Lingual ulcer as the only sign of recurrent mycobacterial infection in an HIV/AIDS-infected patient. Med Oral Patol Oral Cir Bucal 2005;10:109-14.

50. Torres-Lagares D, Serrera-Figallo MA, Romero-Ruíz MM, Infante-Cossío P, García-Calderón M, Gutiérrez-Pérez JL. Alveolitis seca. Actualización de conceptos. Med Oral Patol Oral Cir Bucal 2005; 10:77-85.

51. Von Arx T. Failed Root Canals: The Case for Apicoectomy (Periradicular Surgery). J Oral Maxillofac Surg 2005;63:832-7.

52. Tsesis I, Shoshani Y, Givol N, Yahalom R, Fuss Z, Taicher S. Comparison of quality of life after surgical endodontic treatment using two techniques: A prospective study. Oral Surg Oral Med Oral Pathol Oral Radiol Endod 2005;99:367-71.

53. Martí E, Peñarrocha M, García B. Periapical sugery using the ultrasound technique and silver amalgam retrograde filling. A study of 71 teeth with 100 canals. Oral Surg Oral Med Oral Pathol Oral Radiol Endod 2005;10:E67-73.

54. Taschieri S, Del Fabbro M, Testori T, Francetti L, Weinstein R. Endodontic sugery with ultrasonic retrotips: One-year follow-up. Oral Surg Oral Med Oral Pathol Oral Radiol Endod 2005;100:380-7.

55. Baek SH, Plenk H, Kim S. Periapical tissue responses and cementum regeneration with Amalgam, SuperEBA, and MTA as root-end filling materials. J Endod 2005;31:444-9.

56. Gondim E, Kim S, de Souza-Filho FJ. An investigation of microleakage from. Root-end fillings in ultrasonic retrograde cavities with or without finishing: A quantitative analysis. Oral Surg Oral Med Oral Pathol Oral Radiol Endod 2005;99:755-60.

57. Von Arx T. Frequency and type of canal isthmuses in first molars detected by endoscopies inspection during periradicular surgery. Int Endod J 2005;38:160-16.

58. Velvart $\mathrm{P}$, Peters $\mathrm{Cl}$. Soft tissue management in endodontic surgery. J Endod 2005;31:4-16.

59. Gagliani MM, Gorni FGM, Strohmenger L. Periapical resurgery versus periapical surgery: a 5 year longitudinal comparison. Int Endod / 2005;38:320-7.

60. Mead C, Javidan-Nejad S, Mego ME, Nash B, Torabinejad M. Levels of evidence for the outcome of endodontic sugery. J Endod 2005;31:19-24.

61. Lindeboom J A H, Frenken J W H, Valkenburg P, van den Akker $\mathrm{H}$ $P$. The role of preoperative prophylactic antibiotic administration in periapical endodontic surgery: a randomized, prospective doubleblind placebo-controlled study. Int Endod / 2005;38:877

62. Susarla S, Dodson T. Estimating Third Molar Extraction Difficulty: A comparison of subjective and objective factors. J Oral Maxillofac Surg 2005;63:427-34.

63. Susarla S, Dodson T. How well do clinicians estimate third molar extraction difficulty? J Oral Maxillofac Surg 2005;63:191-9.

64. Mc Ardle LW, Renton TF. Distal cervical caries in the mandibular second molar: indication for the prophylactic removal of the third molar? Br J Oral Maxillofac 2006;44:42-5. Epub 2005 Oct 5.

65. Dodson $\mathrm{T}$. Is there a role for reconstructive techniques to prevent periodontal defects after third molar surgery? J Oral Maxillofac Surg 2005;63:891-6.

66. Sammartino G, Tia M, Marenzi G, Espedito di Lauro A, D’Agostino E, Claudio PP. Use of autologous Plaquetet-Rich plasma in periodontal defects treatment after extraction of impacted mandibular third molars. J Oral Maxillofac Surg 2005;63:766-70.
67. Gomes AC, Vasconcelos BC, de Oliveira e Silva ED, da Silva LC. Lingual nerve damage alter mandibular third molar surgery: a randomized clinical trial. J Oral Maxillofac Surg 2005;63:1443-6

68. Robert RC, Bacchetti P, Pogrel MA. Frequency of trigeminal nerve injuries following third molar removal. J Oral Maxillofac Surg 2005;63:732-5.

69. Queral E, Valmaseda E, Berini L, Gay C. Incidents and evolution of inferior alveolar nerve lesions following lower third molar extraction. Oral Surg Oral Med Oral Pathol Oral Radiol Endod 2005;99:259-64.

70. Renton T, Hankins M, Sproate C, McGurk M. A randomised controlled clinical trial to compare the incident of injury to the alveolar nerve as a result of coronectomy and removal of mandibular third molars. Br J Oral Maxillofac Surg 2005;43:7-12.

71. Sedaghatfar M, Meredith A, Dodoson TB. Panoramic radiographic findings as predictors of inferior alveolar nerve exposure following third molar extraction. J Oral Maxillofac Surg 2005;633-7.

72. Chaparro-Avedaño A, Peréz-García S, Balmaceda-Castellón E, Berini-Aytés L, Gay-Escoda C. Morbidity of third molar extraction in patients between 12 and 18 years of age. Med Oral Patol Oral Cir Bucal 2005; 10:422-31.

73. Pasqualini D, Cocero N, Castella L, Mela L, Bracco P. Primary and secundary closure of the surgical wound after removal of impacted mandibular third molars: a comparative study. Int J Oral MaxiIlofac Surg 2005;34:52-7.

74. Figuereido R, Valmaseda E, Berini L, Gay C. Incidence and clinical features of delayed-onset infections after extraction of lower third molar. Oral Surg Oral Med Oral Pathol Oral Radiol Endod 2005;99:265-9.

75. Esen E, Üstün Y, Balcioglu O, Alparslan N. Evaluation of patient-controlled remifentanil application in third molar surgery. J Oral MaxiIlofac Surg 2005;63:457-63.

76. Chiu WK, Cheung LK. Efficacy of preoperative oral Robecoxib in pain control for third molar surgery. Oral Surg Oral Med Oral Pathol Oral Radiol Endod 2005;99:E47-53.

77. Garcia M, Torres D, Gónzalez M, Gutiérrez JL. Rescue surgery (surgical repositioning) of impacted lower second molars. Med Oral Patol Cir Bucal 2005; 10:448-53.

78. Lewis B, Durning P, McLaughlin W, Nicholson PT. Canine transposition following trauma and loss of a central incisor: treatment options. J Orthod 2005;32:11-9.

79. Kofod T, Würtz V, Melsen B. Treatment of an ankylosed central incisor by single tooth dento-osseous osteotomy and a simple distraction device. Am J Orthod Dentofacial Orthop 2005;127:72-80.

80. Bayrak S, Dalci K, Sari S. Case Report evaluation of supernumerary teeth with computerized tomography. Surg Oral Med Oral Pathol Oral Radiol Endod 2005; 100:65-9.

81. Shapira $Y$, Kuftinec MM. Unusual intraosseous transmigration of a palatally impacted canine. Am J Orthod Dentofacial Orthop 2005;127: 360-3.

82. Kim E, Jung JY, Cha IH, Kum KY, Lee SS. Evaluation of the prognosis and causes of failure in 182 cases of autopens tooth transplantation. Oral Surg Oral Med Oral Pathol Oral Radiol Endod 2005;100: 112-9.

83. Maia RL, Vieira APGF. Auto-transplantation of central incisor with root dilacerations. Technical note. Int J Oral Maxillofacial Surg 2005;34:89-91. 
84. Akkocaoglu M, Oguzcan K. Success rate of autotransplanted teeth without stabilization by splints: a long-term clinical and radiological follow-up. Br J Oral Maxillofacial Surgery 2005;43:31-5.

85. Bauss O, Schwestka R, Schilke R, Kiliaridis S. Effect of different splinting methods and fixation periods on root development of autotransplanted immadure third molars. J Oral Maxillofac Surg 2005;63:304-10.

86. Chappuis V, Von Arx. Replantation of 45 avulsed permanent teeth: a 1-year follow-up study. Dent Traumatol 2005;21:289-96.

87. Pohl Y, Filippi A, Kirschner H. Results after replantation of avulsed permanent. Dent Traumatol 2005;21:80-92.

88. Pohl Y, Filippi A, Kirschner H. Results after replantation of avulsed permanente teeth II. Periodontal healing and the role of physiologic storage and antiresortive-regenerative terapia. Dent Traumatol 2005;21:93-101.

89. Pohl Y, Filippi A, Kirschner H. Results after replantation of avulsed permanent teeth III. Tooth loss and survival analysis. Dent Traumatol 2005;21:102-10.

90. Schjøtt M, Andreasen JO. Emdogain ${ }^{\circledR}$ does not prevent progressive root resorption after replantation of avulsed teeth: a clinical study. Dent Traumatol 2005;21:46-50.

91. Barrett EJ, Kenny DJ, Tenenbaum HC, Sigal MJ, Johnston DH. Replantation of permanent incisors in children using Emdogain ${ }^{\circledR}$. Dent Traumatol 2005;21:269-75.

92. Çaglar E, Tanboga I, Süsal S. Treatment of avulsed teeth with Emdogain $^{\circledR}$ : a case report. Dent Traumatol 2005;21:51-3.

93. Berlin J, Nusstein J, Reader A, Beck M, Weave J. Efficacy of articaine and lidocaine in a primary intraligamentary injection administered with a computer-controlled local anesthesic delivery system. Oral Surg Oral Med Oral Pathol Oral Radiol Endod 2005;99:361-6.

94. Brkovic B, Todorovic L, Stojic D. Comparison of clonidine and epinephrine in lidocaine anaesthesia for lower third molar surgery. Int J Oral Maxillofac Surg 2005;34:401-6.

95. Viana A, de Campos AC, Morlin MT, Chin VKL. Plasma catecholamine concentrations and hemodynamic responses to vasoconstrictor during conventional or Gow-Gates mandibular anesthesia. Oral Surg Oral Med Oral Pathol Oral radiol Endod 2005;100:415-9.

96. Dogan EA, Dora B. Transient partial ophthalmoplegia and Horner's syndrome after intraoral local anesthesia. J Clin Neurosci 2005;12:669-7.

97. Horowitz J, Almog Y, Wolf A, Buckman G, Geyer O. Ophtalmic complications of dental anesthesia: three new cases. J Neuroophthalmol 2005;25:95-100.

98. Pérez-García S, Chaparro-Avendaño AV, Delgado-Molina E, BeriniAytés L, Gay-Escoda C. Day case oral surgery in pediatric patients during the year 2000 in the University of Barcelona Dental Clinic (Spain). Med Oral Patol Oral Cir Bucal 2005;10:221-30.

99. Stubinger S, Leigger C, Sader R, Kunz C. Intraorbital abscess: a rare complication after maxillary molar extraction. J Am Dent Assoc 2005;136:921-5.

100. Bagan JL, Murillo J, Jimenez Y, Poveda R, Milian MA, Sabchis JM, Silvestre $\mathrm{Fl}$, Scully $\mathrm{C}$. Avascular jaw osteonecrosis in association with cancer chemoteraphy: series of 10 cases. J Oral Pathol Med 2005;34: 120-3

101. Jimenez-Soriano Y, Bagan JV. Biphosphonates, as a new cause of drug-induced jaw osteonecrosis: an update. Med Oral Patol Oral Cir Bucal 2005;10 Suppl 2:E88-91. 